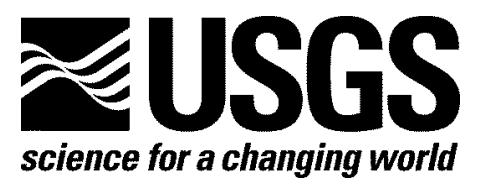

In cooperation with the Los Angeles County Department of Public Works and Water Replenishment District of Southern California

\title{
A 3-Dimensional Model of Water-Bearing Sequences in the Dominguez Gap Region, Long Beach, California
}

By Daniel J. Ponti, Kenneth D. Ehman, Brian D. Edwards, John C. Tinsley, III, Thomas Hildenbrand, John W. Hillhouse, Randall T. Hanson, Kristen McDougall, Charles L. Powell, II, Elmira Wan, Michael Land, Shannon Mahan, Andrei M. Sarna-Wojcicki

U.S. Geological Survey Open-File Report 2007-1013

U.S. Department of the Interior

U.S. Geological Survey 


\section{U.S. Department of the Interior DIRK KEMPTHORNE, Secretary}

\section{U.S. Geological Survey \\ Mark D. Myers, Director}

\section{U.S. Geological Survey, Reston, Virginia 2007}

Revised and reprinted: 2007

For product and ordering information:

World Wide Web: http://www.usgs.gov/pubprod

Telephone: 1-888-ASK-USGS

For more information on the USGS-the Federal source for science about the Earth,

its natural and living resources, natural hazards, and the environment:

World Wide Web: http://www.usgs.gov

Telephone: 1-888-ASK-USGS

Suggested citation:

Ponti, Daniel J., Ehman, Kenneth D., Edwards, Brian D., Tinsley, John C., III, Hildenbrand, Thomas, Hillhouse, John W., Hanson, Randall T., McDougall, Kristen, Powell, Charles L., II, Wan, Elmira, Land, Michael, Mahan, Shannon, and Sarna-Wojcicki, Andrei M., 2007, A 3-Dimensional Model of WaterBearing Sequences in the Dominguez Gap Region, Long Beach, California: U.S. Geological Survey Open-File Report 2007-1013, 34 p.

Any use of trade, product, or firm names is for descriptive purposes only and does not imply endorsement by the U.S. Government.

Although this report is in the public domain, permission must be secured from the individual copyright owners to reproduce any copyrighted material contained within this report. 


\section{Contents}

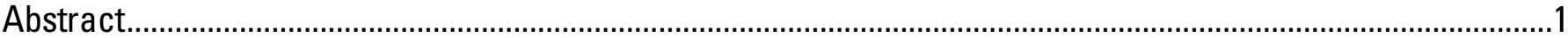

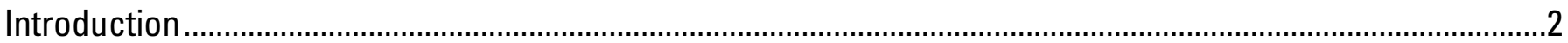

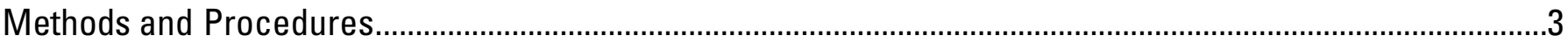

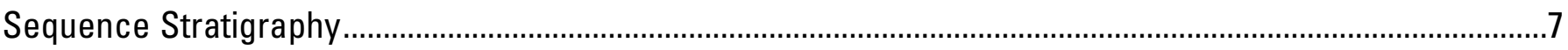

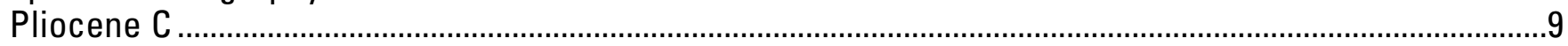

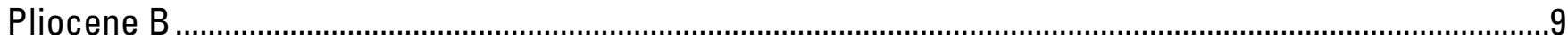

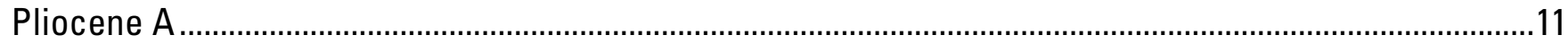

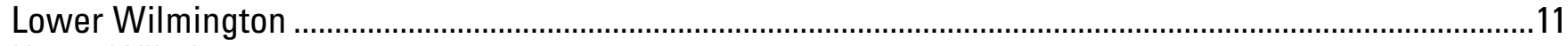

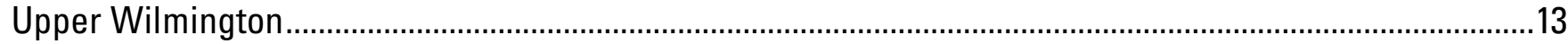

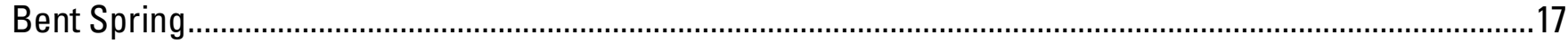

Harbor

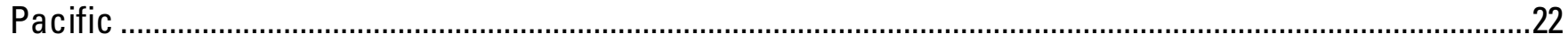

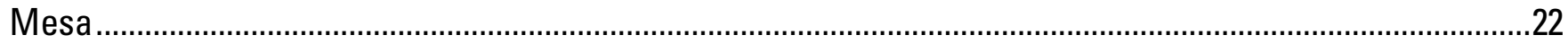

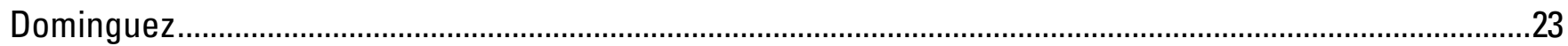

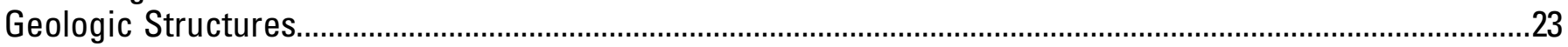

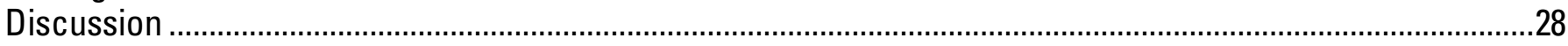

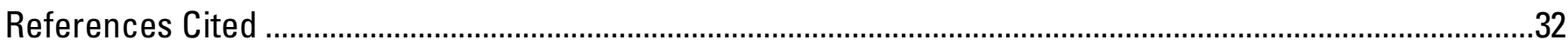

\section{Figures}

Figure 1. Map showing the simplified surface sequence geology of the Dominguez Gap model space. ....... 4

Figure 2. EarthVision 3D rendering of the Dominguez Gap model region.

Figure 3. Chair slice through the $3 \mathrm{D}$ model, showing structure and stratigraphy beneath the Los Angeles river channel extending from San Pedro Bay north into Long Beach. ......................................................... 8

Figure 4. Correlation diagram showing the occurrences of major sequences (colored layers) identified in the five core holes drilled in the Long Beach area..

Figure 5. Age control on stratigraphic sequences in the Long Beach region as obtained from various relative and absolute dating analyses on core samples...............................................................................10

Figure 6. Magnetic intensity and susceptibility as measured from core samples............................................11

Figure 7. North-south section line through the Dominguez Gap EarthVision model .....................................12

Figure 8. Section line from the EarthVision model along the Dominguez Gap seawater intrusion barrier

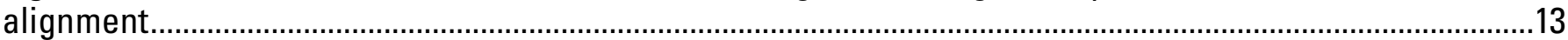

Figure 9. Age estimates of the Pleistocene sequences based on existing geochronologic data and correlation with the oxygen-isotope paleoclimate and geomagnetic intensity records....................................14

Figure 10. Structure contour map on the top of the Upper Wilmington sequence ...........................................18

Figure 11. Isochore (vertical thickness) map for the Upper Wilmington sequence ..........................................19

Figure 12. Chloride concentrations and oxygen 18/16 ratios from the LBCH core hole ..................................20

Figure 13. Isostatic gravity anomaly map and residual isostatic gravity anomaly map of the Dominguez Gap

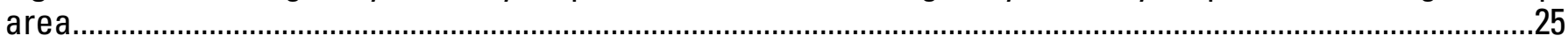

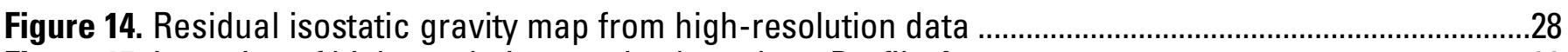

Figure 15. Inversion of high resolution gravity data along Profile A ..........................................................30

Figure 16. Residual gravity map of the Dominguez gap region showing the relationship between gravity and possible fault strands. 


\section{Tables}

Table 1. Borehole and well screen information for USGS reference core holes used in this study 5

Table 2. Summary of seismic velocities used for depth conversion from synthetic seismograms and geologic boundaries

Table 3. Correlation table relating sequence geology north of the $\mathrm{PCH}$ fault to formations and aquifer nomenclature in the Long Beach/Dominguez Gap region.

Table 4. Correlation table relating sequence geology south of the $\mathrm{PCH}$ fault to formations and aquifer nomenclature in the Long Beach/Dominguez Gap region.

\section{Conversion Factors}

\section{Inch/Pound to SI}

\begin{tabular}{lcl}
\hline \multicolumn{1}{c}{ Multiply } & By & \multicolumn{1}{c}{ To obtain } \\
\hline & Length & \\
\hline foot $(\mathrm{ft})$ & 0.3048 & meter $(\mathrm{m})$ \\
mile $(\mathrm{mi})$ & 1.609 & kilometer $(\mathrm{km})$ \\
\hline & Density & \\
\hline pound per cubic foot $\left(\mathrm{lb} / \mathrm{ft}^{3}\right)$ & 16.02 & kilogram per cubic meter $\left(\mathrm{kg} / \mathrm{m}^{3}\right)$ \\
pound per cubic foot $\left(\mathrm{lb} / \mathrm{ft}^{3}\right)$ & 0.01602 & $\begin{array}{l}\text { gram per cubic centimeter } \\
\left(\mathrm{g} / \mathrm{cm}^{3}\right)\end{array}$ \\
\hline
\end{tabular}

\section{SI to Inch/Pound}

\begin{tabular}{lcl}
\hline \multicolumn{1}{c}{ Multiply } & By & \multicolumn{1}{c}{ To obtain } \\
\hline meter $(\mathrm{m})$ & Length & \\
kilometer $(\mathrm{km})$ & 3.281 & foot $(\mathrm{ft})$ \\
& 0.6214 & mile $(\mathrm{mi})$ \\
\hline kilogram per cubic meter $\left(\mathrm{kg} / \mathrm{m}^{3}\right)$ & Density & \\
gram per cubic centimeter $\left(\mathrm{g} / \mathrm{cm}^{3}\right)$ & 0.06242 & pound per cubic foot $\left(\mathrm{lb} / \mathrm{ft}^{3}\right)$ \\
\hline
\end{tabular}

Vertical coordinate information is referenced to the North American Vertical Datum of 1988 (NAVD 88). Horizontal coordinate information is referenced to the North American Datum of 1983 (NAD 83)..

Altitude, as used in this report, refers to distance above the vertical datum.

Concentrations of chemical constituents in water are given either in milligrams per liter (mg/L) or micrograms per liter $(\mu \mathrm{g} / \mathrm{L})$. 


\title{
A 3-Dimensional Model of Water-Bearing Sequences in the Dominguez Gap Region, Long Beach, California
}

\author{
By Daniel J. Ponti, Kenneth D. Ehman, Brian D. Edwards, John C. Tinsley, Thomas Hildenbrand, John \\ W. Hillhouse, Randall T. Hanson, Kristen McDougall, Charles L. Powell II, Elmira Wan, Michael Land, \\ Shannon Mahan, Andrei M. Sarna-Wojcicki
}

\begin{abstract}
A 3-dimensional computer model of the Quaternary sequence stratigraphy in the Dominguez gap region of Long Beach, California has been developed to provide a robust chronostratigraphic framework for hydrologic and tectonic studies. The model consists of 13 layers within a 16.5 by $16.1 \mathrm{~km}(10.25$ by 10 mile) square area and extends downward to an altitude of -900 meters ( -2952.76 feet). Ten sequences of late Pliocene to Holocene age are identified and correlated within the model. Primary data to build the model comes from five reference core holes, extensive high-resolution seismic data obtained in San Pedro Bay, and logs from several hundred water and oil wells drilled in the region. The model is best constrained in the vicinity of the Dominguez gap seawater intrusion barrier where a dense network of subsurface data exist. The resultant stratigraphic framework and geologic structure differs significantly from what has been proposed in earlier studies.

An important new discovery from this approach is the recognition of ongoing tectonic deformation throughout nearly all of Quaternary time that has impacted the geometry and character of the sequences. Anticlinal folding along a NW-SE trend, probably associated with Quaternary reactivation of the Wilmington anticline, has uplifted and thinned deposits along the fold crest, which intersects the Dominguez gap seawater barrier near Pacific Coast Highway. A W-NW trending fault system that approximately parallels the fold crest has also been identified. This fault progressively displaces all but the youngest sequences down to the north and serves as the southern termination of the classic Silverado aquifer.

Uplift and erosion of fining-upward paralic sequences along the crest of the young fold has removed or thinned many of the fine-grained beds that serve to protect the underlying Silverado aquifer from seawater contaminated shallow groundwater. As a result of this process, the potential exists for vertical migration of seawater into the producing aquifers and subsequent landward migration of intruded waters beneath the existing Dominguez barrier. Incipient invasion of the Silverado aquifer by chloride-enriched waters is observed in a recently drilled well located along the crest of the fold seaward of the barrier and at a depth of 440 feet (134 meters).

These new observations and interpretations indicate that the new sequence-based approach to defining the stratigraphy of the Dominguez Gap area may have important implications for seawater intrusion management. To test this, it will be useful to overlay existing water-quality and water level data onto the framework model and to incorporate the new stratigraphy into a transport model.
\end{abstract}




\section{Introduction}

This report briefly summarizes the results of a series of studies conducted by the U.S. Geological Survey in cooperation with the Water Replenishment District of Southern California (WRDSC) and the Los Angeles County Department of Public Works (LACDPW) to construct a 3-dimensional computer model of the Quaternary sequence stratigraphy in the Dominguez gap region of Long Beach, California. This effort is part of a larger, integrated evaluation of the geohydrology, ground-water flow, and ground-water geochemistry of the Los Angeles basin that is currently underway by the USGS and its cooperators (e.g. Reichard and others, 2003; Land and others, 2004). The stratigraphic model, which was constructed using EarthVision ${ }^{1}$ software, is designed to serve as a basic framework for concurrent and follow-on hydrologic and tectonic studies. Because the model is in digital form, it can be easily refined, modified, and updated as additional data become available and incorporated, and can also serve multiple purposes. For example, current USGS efforts are underway in cooperation with WRDSC to test the hydraulic impacts of this framework in a transport model and to evaluate various scenarios of seawater migration into the Dominguez gap region.

This geologic model is significantly different from others developed in the past, both regionally and locally. Previous studies of the subsurface geology of the region for ground-water evaluations (eg. Poland and others, 1956; California Dept. of Water Resources, 1961; Zielbauer and others, 1962) produced their subsurface correlations by attempting to tie together deposits of similar lithologies from well log descriptions; few electric logs, detailed paleoenvironmental information, or other geophysical data were available relative to the present day. These lithostratigraphic correlations tie together packages of sediment based upon similar gross lithology and depth below ground surface (as a proxy for stratigraphic position). While this approach is useful for defining zones in the subsurface where aquifer materials exist, it does not rationally account for lateral variations in lithology due to facies changes, and the bounding surfaces of these units may not appropriately serve as useful geochronologic boundaries. As such, lithostratigraphic correlations may not provide much valid insight into basin history, the true continuity of coarse-grained water-bearing facies, or the interconnection among such deposits. In contrast, this new model incorporates the concept of sequence stratigraphy, an approach that ties together packages of sediment that are genetically related and deposited within a specified interval of time, even as their lithologies may vary both laterally and vertically. A sequence consists of sediment that records a series of depositional events related in time and space. Sequences and their vertical stacking are controlled by base level (sea level) change, sediment supply, and available accommodation space. Within these depositional systems, the various facies have lateral relationships that are mappable and predictable, thus allowing for the lateral distribution of aquifers and their confining fine-grained aquitards to be better defined. Vertical connections among aquifers are controlled by the depositional environments within each sequence, and also by how sequences stack up on top of one another. Both lateral and vertical juxtapositions of facies can also be impacted by geologic structures and the sequence stratigraphic approach can help to define these as well.

Therefore, sequences are allostratigraphic units, rather than the lithostratigraphic units defined by previous workers (Poland and others, 1956; California Dept. of Water Resources, 1961; Zielbauer and others, 1962); they are mappable units defined by their bounding discontinuities and not by their lithologic characteristics. Within the study area, sequences are bounded top and bottom by regionally unconformable surfaces upon which there is generally some evidence for erosion. While these sequence-bounding unconformities are not strictly isochronous surfaces, they are important markers

\footnotetext{
${ }^{1}$ Any use of trade, product or firm names in this document is for descriptive purposes only and does not imply endorsement by the U.S. Government.
} 
because sediment deposited above an unconformity is everywhere younger than sediment that underlies that unconformity. As such, sequence boundaries can serve as proxies for developing a chronostratigraphic, or time-based framework with which to correlate deposits. In the Los Angeles coastal plain, the geologic sequences of Quaternary age generally form in response to sea level changes resulting from worldwide cycles of glaciation (Imbrie and others, 1984). Ongoing folding and faulting during deposition further complicate the sedimentary patterns. In the study area, most sediment accumulation in this coastal region appears to have occurred during interglacial periods when sea levels were high and coastlines prograded across the shelf. During glacial periods when sea levels were low, significant erosion and sediment bypass into the ocean basins occurred, producing the unconformities. The sequences and their boundaries can be identified by characteristic cycles of coarsening or fining upward packages that reflect sediment progradation and retrogradation. These cycles can often be recognized and correlated in well electric and lithologic logs even where gross lithologies or electric log signatures are vastly different. Evidence for truncation and onlap at sequence boundaries can also be observed in seismic reflection profiles. A combination of both well log and seismic data was used for sequence identification and correlation in this study.

The value of sequence stratigraphy is that a more realistic assessment of the subsurface geology and basin tectonic history can be realized. Sequence stratigraphy is important for ground-water studies because it provides for more robust prediction of hydraulic properties as well as assessing the potential for aquifer connectivity along structural discontinuities such as angular unconformities and faults. Within a given sequence, coarse-grained deposits that may serve as productive aquifers might, for example, transition laterally toward the coastline from river channel sands and gravels, to coastal dunes and tidal channel sands, to intertidal and neritic marine sands. Ground-water flow might be expected to flow naturally between these facies within a sequence because of their interconnections, and will also be controlled by the hydraulic properties of the various facies. Movement of ground water between sequences can certainly take place as well, but will most readily occur where the coarse-grained facies of two sequences are juxtaposed. Such occurrences can occur laterally due to channel incision or faulting, or vertically where coarse-grained deposits are adjacent to the sequence boundary. Once the aquifer architecture within sequences is understood, however, likely interconnections among sequences can be readily estimated and incorporated into flow and transport models.

\section{Methods and Procedures}

To aid in developing the sequence stratigraphic model, the USGS, in cooperation with WRDSC and LACDPW, drilled 5 boreholes in the region to depths of more than 1500 feet (457 meters) that were continuously or extensively cored (Figure 1; Table 1). The cores were described in detail and subjected to extensive analyses that yielded important information on sediment depositional environment, age, and physical and geochemical properties. The core holes were also logged with various geophysical tools to provide a basis to tie into existing log data in the region. The core holes serve as reference sections for the overall study; it is from these holes that most of the principal sequences are identified and classified with respect to age, depositional environment, and sediment physical properties. Following drilling, each hole was completed as a multiple monitoring well site similar to those described by Land and others (2002).

Two of the core holes were drilled at the Port of Long Beach, within San Pedro Bay. These wells were located adjacent to ship channels so that they could be tied into a series of shipboard sleeve gun seismic reflection profiles that were obtained by the USGS as part of the overall LA Basin study (Figure 1). These data were interpreted along nearby well picks to delineate the major sequence boundaries that generally trend away from the current coastline. As a part of this process, the submarine outcrop limits 
of the two youngest sequences were interpreted in the coastal region of Long Beach Harbor. The twoway travel times to each of the major sequence boundaries and the ocean bottom were then digitized and depth converted on the basis of seismic velocities estimated for each unit from the Pier C and Pier F core holes (Table 2).

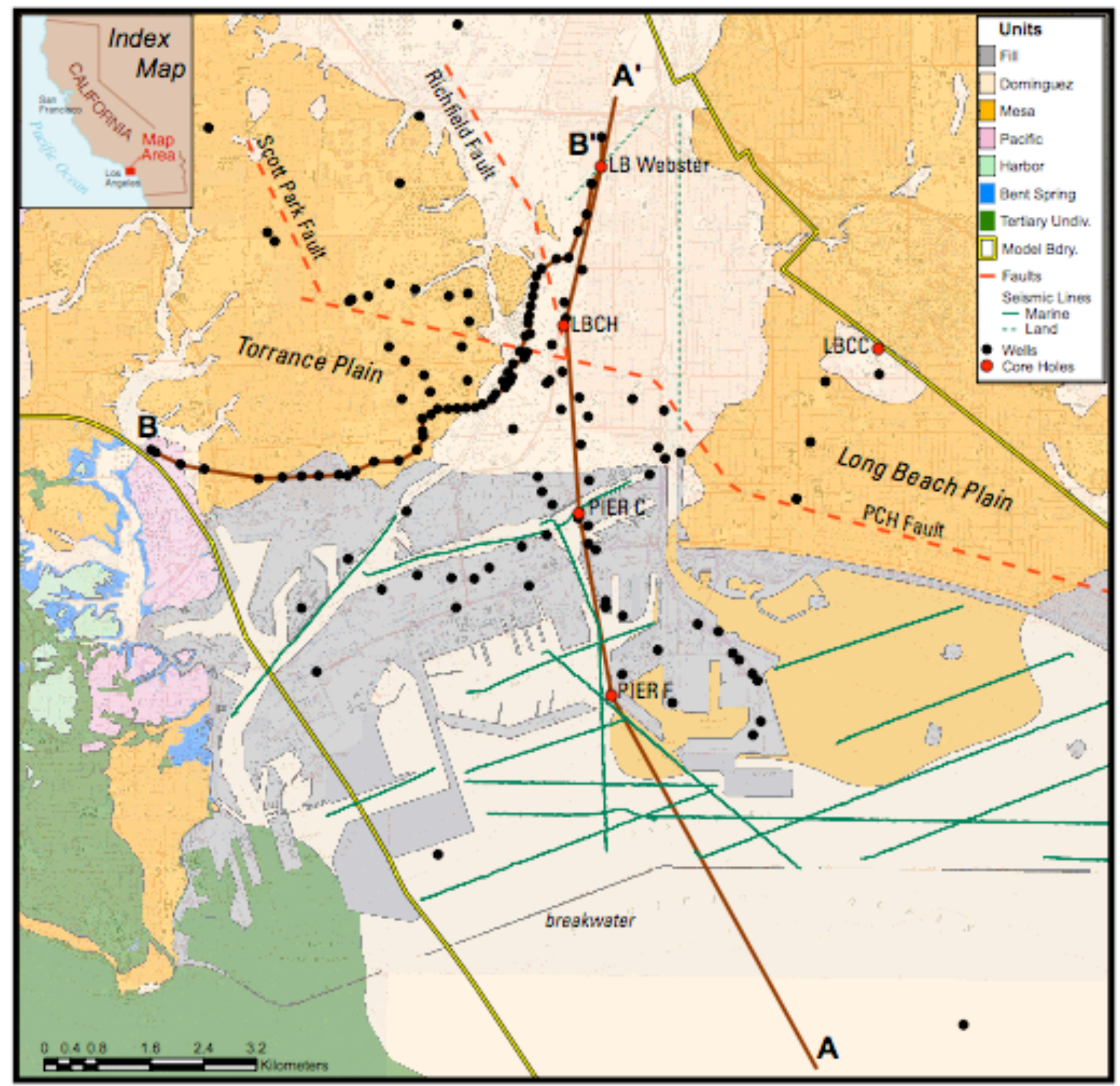

Figure 1. Map showing the simplified surface sequence geology of the Dominguez Gap model space (modified from unpublished California Geological Survey data). Boreholes used in the model (black dots), USGS continuously cored boreholes (red dots), USGS seismic-reflection lines (green lines), and EarthVision interpreted section line locations (A-A' and B- $B^{\prime}$ ) are shown. The surface projections of the concealed PCH, Richfield, and Scott Park fault zones are also shown as dashed red lines. 
Additional data gathering involved 1) a land seismic reflection/refraction profile along the Los Angeles River (which has not yet provided much useful information below the Gaspur aquifer), and 2) high-resolution gravity measurements to help provide constraints on the geometry of buried features, such as faults and channels.

Following identification of sequence boundaries from the cores and seismic sections, a series of cross sections were constructed utilizing both seismic and well data in order to assign the sequences to other wells and seismic reflectors in the region, and to identify faults and fold trends. We canvassed all available well log information from the area, including logs files made available to us by the LACDPW and California Division of Oil and Gas. Of the several thousand oil wells drilled in the Wilmington oil field, most were not logged in the upper 1000 feet or were deviated wells for which survey data was not made available to us, and were therefore not used. However, we did compile a representative subset of industry data that did have logs in the shallow section. In total, over 300 water and oil well logs in the region were compiled, digitized and interpreted in this process. Approximately $1 / 2$ of these logs, which comprise the best and most representative of the available data, and focused on the Dominguez gap barrier, are incorporated in the present model (Figure 1).

Table 1. Borehole and well screen information for USGS reference core holes used in this study

\begin{tabular}{|c|c|c|c|c|c|c|c|}
\hline $\begin{array}{l}\text { Names used } \\
\text { in this report }\end{array}$ & $\begin{array}{l}\text { USGS/WRDSC } \\
\text { Common Name } \\
\end{array}$ & $\begin{array}{l}\text { Easting } \\
\text { (UTM } \\
\text { Zone 11, } \\
\text { meters) }\end{array}$ & $\begin{array}{l}\text { Northing } \\
\text { (UTM } \\
\text { Zone 11, } \\
\text { meters) } \\
\end{array}$ & $\begin{array}{c}\text { Land } \\
\text { Surface } \\
\text { Altitude } \\
\text { (feet) } \\
\end{array}$ & $\begin{array}{l}\text { Hole } \\
\text { Depth } \\
\text { (feet) }\end{array}$ & Well Name & $\begin{array}{c}\text { Depth of } \\
\text { Perforations } \\
\text { (feet below } \\
\text { land } \\
\text { surface) } \\
\end{array}$ \\
\hline $\begin{array}{l}\text { Long Beach } \\
\text { - Webster } \\
\text { (LB } \\
\text { Webster) }\end{array}$ & Long Beach-3 & 387316.67 & 3742645.12 & 25.64 & 1404 & $\begin{array}{l}\text { Long Beach-3 \#1 } \\
\text { Long Beach-3 \#2 } \\
\text { Long Beach-3 \#3 } \\
\text { Long Beach-3 \#4 } \\
\text { Long Beach-3 \#5 }\end{array}$ & $\begin{array}{l}1350-1390 \\
997-1017 \\
670-690 \\
530-550 \\
410-430\end{array}$ \\
\hline $\begin{array}{l}\text { Long Beach } \\
\text { - Pier C } \\
\text { (Pier C) }\end{array}$ & Long Beach-4 & 386982.71 & 3737429.04 & 12.17 & 1401 & $\begin{array}{l}\text { Long Beach-4 \#1 } \\
\text { Long Beach-4 \#2 }\end{array}$ & $\begin{array}{l}1200-1220 \\
800-820\end{array}$ \\
\hline $\begin{array}{l}\text { Long Beach } \\
\text { - Pier F } \\
\text { (Pier F) }\end{array}$ & Long Beach-5 & 387471.75 & 3734680.73 & 12.71 & 1203 & $\begin{array}{l}\text { Long Beach-5 } \# 1 \\
\text { Long Beach-5 } \# 2\end{array}$ & $\begin{array}{l}1090-1110 \\
335-355\end{array}$ \\
\hline $\begin{array}{l}\text { Long Beach } \\
\text { - Cabrillo } \\
\text { High School } \\
(\mathrm{LBCH})\end{array}$ & Long Beach-7 & 386760.65 & 3740255.17 & 18.59 & 1412 & $\begin{array}{l}\text { Long Beach-7 \#1 } \\
\text { Long Beach-7 \#2 } \\
\text { Long Beach-7 \#3 } \\
\text { Long Beach-7 \#4 }\end{array}$ & $\begin{array}{l}1180-1200 \\
650-670 \\
470-490 \\
360-380\end{array}$ \\
\hline $\begin{array}{l}\text { Long Beach } \\
\text { - City } \\
\text { College } \\
\text { (LBCC) }\end{array}$ & Long Beach-8 & 391491.89 & 3739898.51 & 19.56 & 1515 & $\begin{array}{l}\text { Long Beach-8 \#1 } \\
\text { Long Beach-8 \#2 } \\
\text { Long Beach-8 \#3 } \\
\text { Long Beach-8 \#4 } \\
\text { Long Beach-8 \#5 } \\
\text { Long Beach-8 \#6 }\end{array}$ & $\begin{array}{l}1435-1455 \\
1020-1040 \\
780-800 \\
635-655 \\
415-435 \\
165-185\end{array}$ \\
\hline
\end{tabular}


The sequence stratigraphic model was constructed by merging the sequence boundary picks and fault data with existing surficial geologic map and topographic data. Best available surficial geologic mapping (unpublished data from G. Saucedo, California Geological Survey, 2005) at 1:24000 scale was compiled and digitized for inclusion into the model (Figure 1). To conform to the nomenclature defined later in this report, surficial geologic map units identified to be of Holocene age are classified into the Dominguez sequence, Pleistocene-age alluvial and low-lying paralic deposits are classified into the Mesa sequence, and paralic deposits of the low marine terrace north of San Pedro (Palos Verdes sand) are classified into the Pacific sequence. Topographic data on land are derived from USGS 10-meter spacing digital elevation models. Offshore, bathymetric data was obtained from the Los Angeles and Long Beach harbors, NOAA spot bathymetry, and recently collected multibeam swath bathymetry (Dartnell and others, 2004). Because these various datasets have different grid spacing and were collected using different reference elevations, we converted them to a standardized elevation grid for the model space (30 m grid spacing) in the NAVD88 datum, utilizing the National Geodetic Survey program VERTCON (http://www.ngs.noaa.gov/TOOLS/Vertcon/vertcon.html) to compute the datum shifts, and ArcGIS for the final grid construction (Devlin and Ponti, in prep.).

Table 2. Summary of seismic velocities used for depth conversion from synthetic seismograms and geologic boundaries

\begin{tabular}{|l|l|l|l|l|}
\hline $\begin{array}{c}\text { Sequence } \\
\text { defined in this } \\
\text { report }\end{array}$ & $\begin{array}{c}\text { Velocity at } \\
\text { Pier C } \\
\text { (m/sec) }\end{array}$ & $\begin{array}{c}\text { Pier C } \\
\text { Depth to } \\
\text { base of } \\
\text { sequence } \\
\text { (feet) }\end{array}$ & $\begin{array}{c}\text { Velocity at } \\
\text { Pier F } \\
\text { (m/sec) }\end{array}$ & \multicolumn{1}{|c|}{$\begin{array}{c}\text { Pier F } \\
\text { Depth } \\
\text { (feet) }\end{array}$} \\
\hline Water & 1500 & N.P. $^{1}$ & 1500. & N.P. ${ }^{1}$ \\
\hline Dominguez & 1656 & 175 & 1649 & 67 \\
\hline Mesa & $====$ & N.P. $^{1}$ & $====$ & 138 \\
\hline Pacific & $====$ & N.P. $^{1}$ & & \\
\hline Harbor & 1690 & 220 & 1720. & 318 \\
\hline Bent Spring & $====$ & N.P. ${ }^{1}$ & 1848. & 757 \\
\hline $\begin{array}{l}\text { Upper } \\
\text { Wilmington }\end{array}$ & & & & \\
\hline $\begin{array}{l}\text { Lower } \\
\text { Wilmington }\end{array}$ & 1724 & 680 & 1823. & 965 \\
\hline Pliocene-A & 1832 & 828 & 1953 & 1153 \\
\hline Pliocene-B & 1855 & $1390^{2}$ & $====$ & $1700^{2}$ \\
\hline Pliocene-C & $====$ & $1660^{2}$ & $====$ & $2060^{2}$ \\
\hline
\end{tabular}

${ }^{1}$ N.P. = unit not present.

${ }^{2}$ Base of unit projected into location of wellbore.

The present model space is a 16.5 by $16.1 \mathrm{~km}$ ( 10.25 by 10 mile) square area centered over the Dominguez gap barrier and extending into San Pedro Bay (Figure 1). The model is confined between the Palos Verdes and Newport-Inglewood fault zones and extends down to an altitude of -900 meters (2952.76 feet). The model currently consists of thirteen layers (including water and artificial fill) and four fault blocks. The 3D model itself is shown in Figures 2 and 3. 


\section{Sequence Stratigraphy}

Within the model space, we define ten sequences that overlie undifferentiated Tertiary-age "basement". Nine of these sequences are defined from the five reference core holes, and the tenth (Pliocene C), from seismic and oil well electric log data. Correlation diagrams and summary age control for the sequences in the core holes are given in Figures 4 through 6. Two cross-sections derived from the model are also provided to illustrate the stratigraphic relations and geologic structure. One is a N-S line (Figure 7) that passes through four of the core holes and is therefore the best-constrained section. Another (Figure 8) runs along the Dominguez barrier itself.

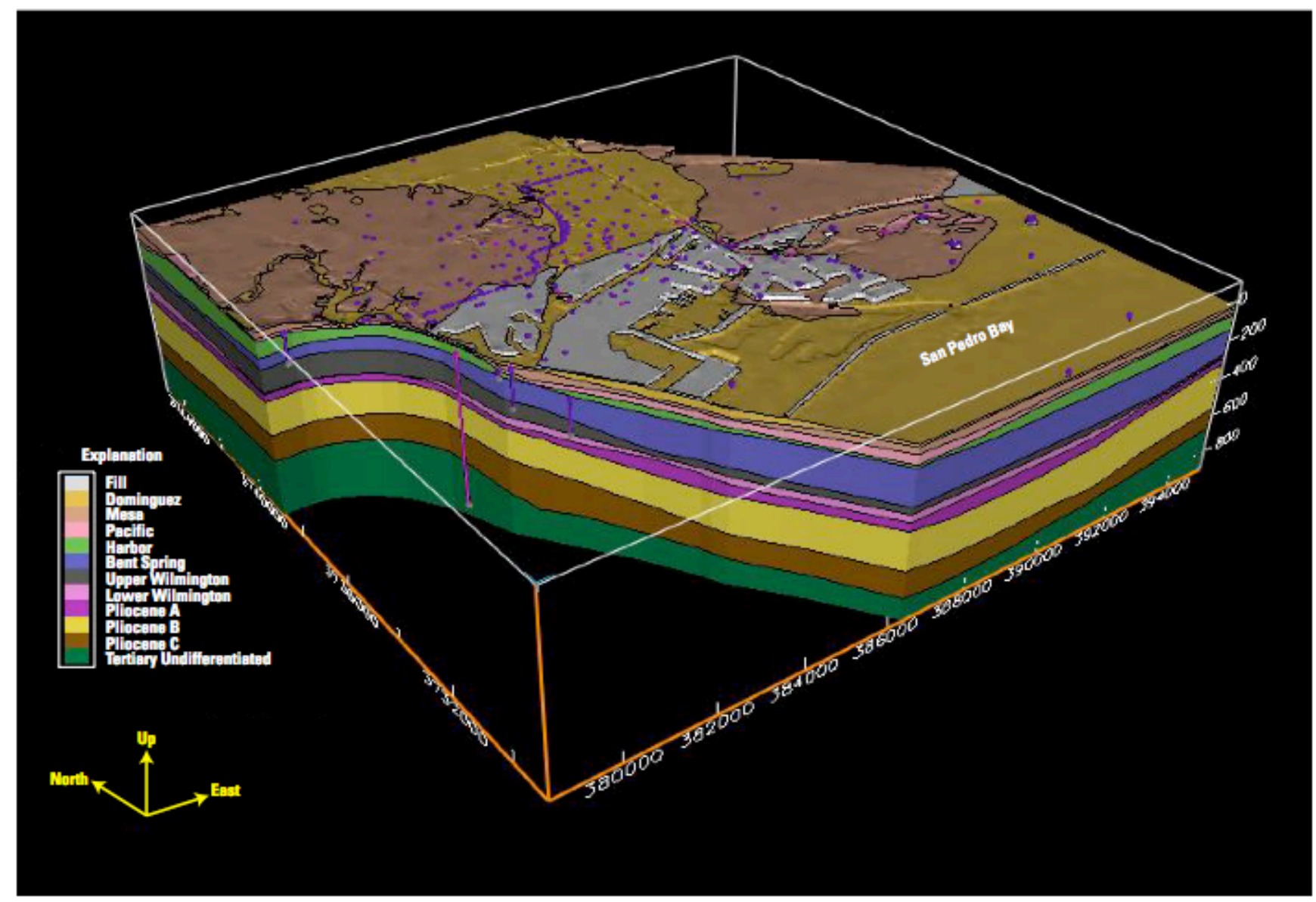

Figure 2. EarthVision 3D rendering of the Dominguez Gap model region showing borehole locations (purple traces). X-Y coordinates are in UTM meters (NAD83 datum) and altitude is in NAVD88 meters. Vertical exaggeration is 5:1. The Palos Verdes fault zone bounds the model on the southwest and the Newport-Inglewood fault zone comprises the northeast boundary. Water in San Pedro Bay has been removed from this illustration to expose the surficial geology of the sea floor.

Because there is no simple association between the chronostratigraphic sequences defined herein and current lithostratigraphic and aquifer nomenclature, we introduce a new set of names for the sequences, which we can then correlate to the paleomagnetic and marine oxygen isotope records (Figure 9). Many of the names derive from Ponti (1989) who defined a chronostratigraphic framework for 
marine deposits of the southwest Los Angeles basin using an amino acid racemization dating technique on fossil shells. Many of Ponti's amino-acid assemblage zones generally fit well within the current sequence framework, so it made sense to use these terms. In addition to the sequences, we have also refined the location and displacement sense of the Richfield fault (reported in Zielbauer and others, 1962), and identified another system of faults that intersects the Dominguez gap barrier just north of Pacific Coast Highway (Figure 1). This structure, which we informally call the Pacific Coast Highway $(\mathrm{PCH})$ fault, displaces all but the youngest of the sequences. The character and thickness of many of the sequences are significantly affected by this fault, and it appears to serve as the southernmost boundary of the thick sand body identified as the type Silverado aquifer by Poland and others (1956). A small fault, ancillary to the PCH fault (the Scott Park fault), is suggested by current data but its existence and geometry are poorly constrained.

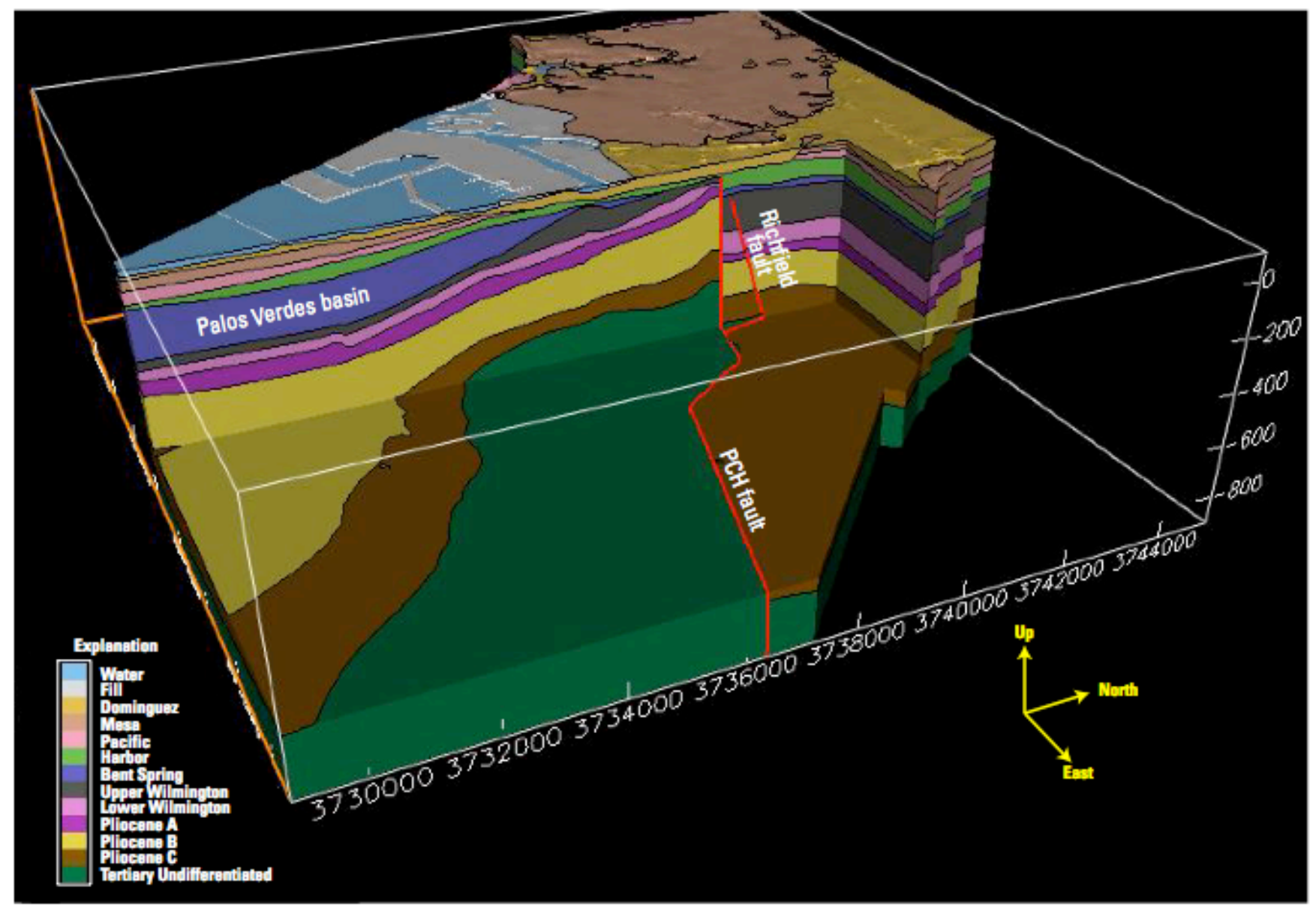

Figure 3. Chair slice through the $3 \mathrm{D}$ model, showing structure and stratigraphy beneath the Los Angeles river channel extending from San Pedro Bay north into Long Beach. Note the thickening of the Bent Spring sequence (dark blue) into the Palos Verdes basin and faulting of the sequences near the crest of the prominent anticline. The thick Upper Wilmington sequence (dark grey) northeast of the Pacific Coast Highway and Richfield faults contains the classic Silverado aquifer of Poland and others (1956). 
As mentioned above, there is no simple correspondence between the sequences and either current aquifer or stratigraphic nomenclature because those units are defined by different criteria. However, a general correlation among the sequences, aquifers and other stratigraphic markers can be accomplished for either side of the PCH fault; these correlations are given in Tables 3 and 4 . With a few exceptions, individually named aquifers typically fall within more than one sequence, and there is little correspondence among aquifers across the $\mathrm{PCH}$ fault. By incorporating this sequence stratigraphic framework, improved characterization of the hydraulic properties, and a better understanding of the hydraulic connections among these previously defined aquifers will be possible.

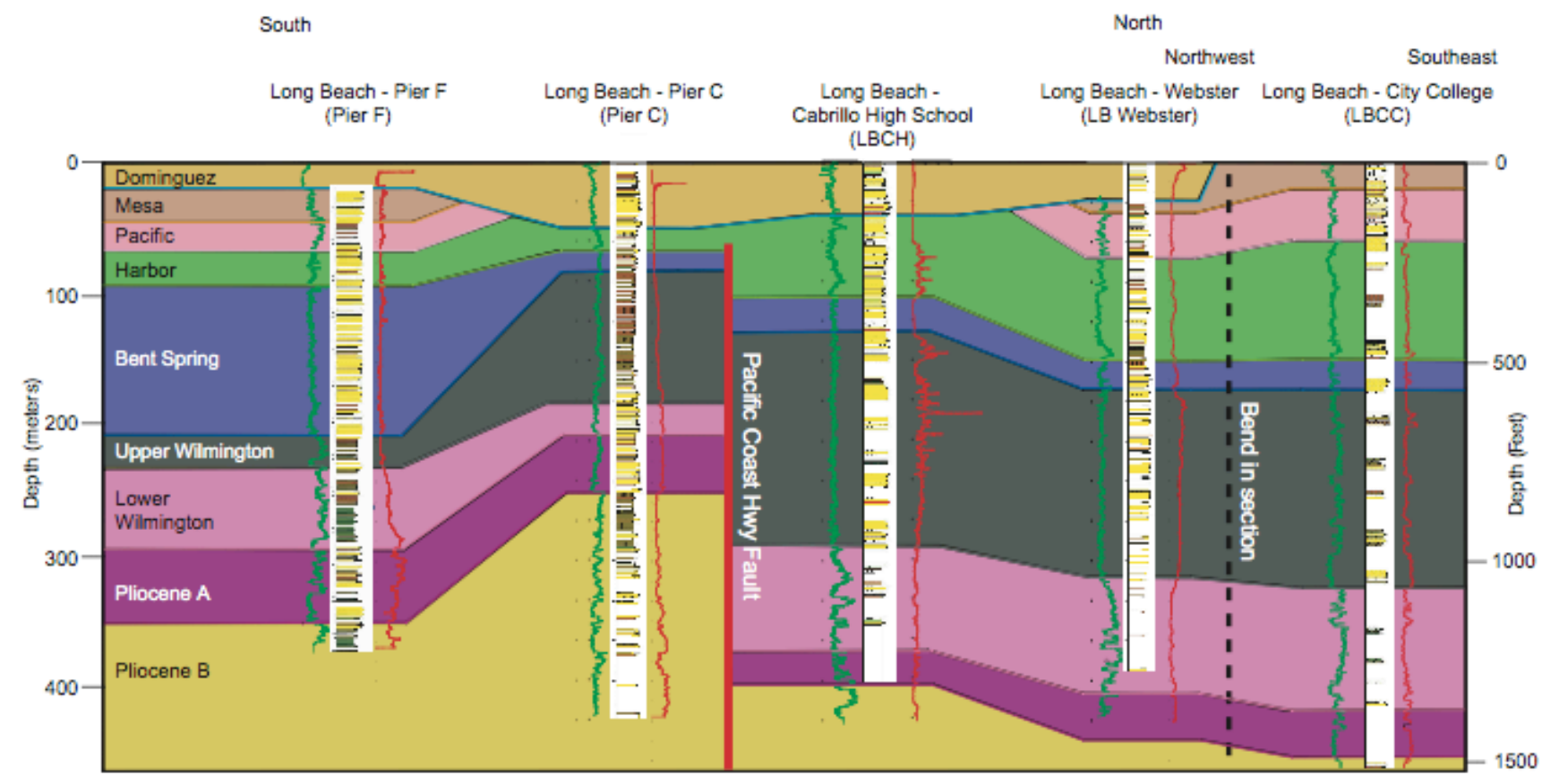

Figure 4. Correlation diagram showing the occurrences of major sequences (colored layers) identified in the five core holes drilled in the Long Beach area. These core holes serve as a standard reference for constraining correlations across the region. The lithology log column shows the generalized lithologies as described from core: orange = gravels, yellow = sand, brown = silt, green = clay. Blank areas of the columns are uncored intervals. Width of the column reflects the median grain size (wider = coarser grained). Red trace next to the lithologic log is the short normal or 20" array induction resistivity; green trace is the gamma log.

\section{Pliocene C}

The oldest defined sequence is identified from seismic and electric log signatures but not encountered in the core holes. The sequence is $60-100 \mathrm{~m}$ thick throughout most of the model space but is poorly constrained. Pliocene $\mathrm{C}$ is undoubtedly of marine origin and is Pliocene in age based on oil industry studies (Wright, 1991). In San Pedro Bay, the unit consists of a basal fining-upward sand about 12-15 m thick, and then generally coarsens upward. The base of the unit (top of the Undifferentiated Tertiary) is marked by a significant reduction in resistivity with very quiet log character below the boundary. This surface appears to correlate with horizon "L", a locally designated marker used by the oil industry in the Wilmington field (Norton and Otott, 1996; Donald Clarke, written communication, 2006). The base of Pliocene $C$ is a major angular unconformity that truncates the crest of the 
Wilmington anticline and separates Upper Pliocene "Pico" rocks from underlying Lower Pliocene Repettian sediment (Norton and Otott, 1996). This surface has also been interpreted by the California Dept. of Water Resources (1961) as the contact between relatively fresh ground waters and underlying more saline waters.

\section{Pliocene B}

Pliocene B was encountered in the Pier C and Pier F core holes and has been referred to the Pico Formation of Wright (1991). The sequence is typically expressed as a generally fining-upward package, possibly reflective of a marine transgression, with a sandy base eventually grading up into silts. The sequence is entirely of marine origin in the study region. Microfauna suggest deposition at lower slope to upper middle bathyal water depths $(500-900 \mathrm{~m})$. The sands in the sequence are of probable turbidite origin. Electric logs show a sharp contact of relatively high resistivity at the base of the unit, which correlates with horizon "JF" in the Wilmington oil field (Norton and Otott, 1996; Donald Clarke, written communication, 2006). The sequence is of fairly uniform thickness ( $200 \mathrm{~m}$ thick). On the north side of the PCH fault, Zielbauer and others (1962) assign the Pico aquifer to wells that penetrate this sequence whereas they assign the lower Silverado aquifer to wells that penetrate this unit south of the fault.

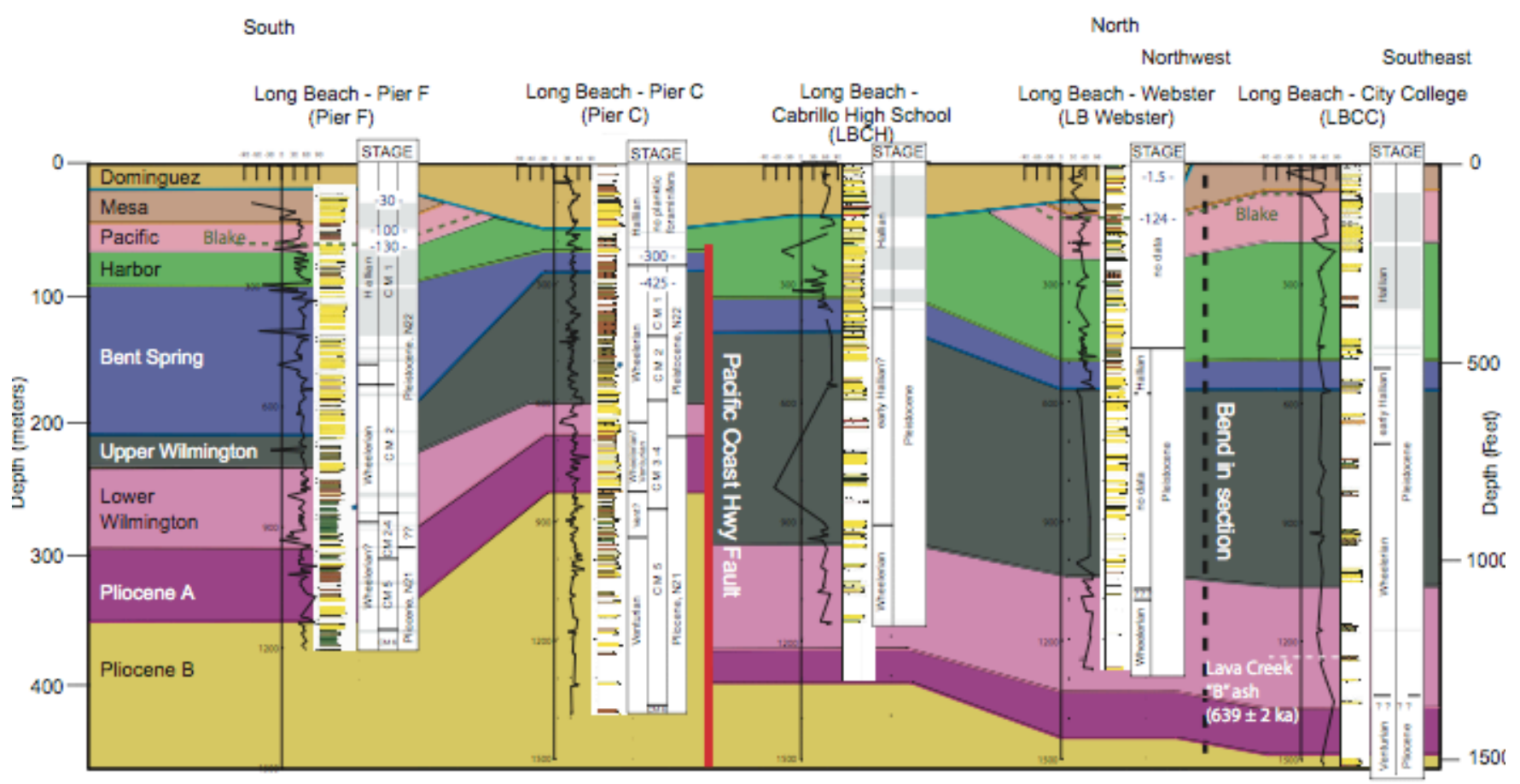

Figure 5. Age control on stratigraphic sequences in the Long Beach region as obtained from various relative and absolute dating analyses on core samples: 1) paleomagnetic inclination data (black line traces); the Blake Event (green), a paleomagnetic excursion that occurred $~ 115$ ky ago has been identified in 3 of the core holes, 2) microfossil age/stages (white panels), 3) sediment luminescence dates (average values, in thousands of years, shown in blue on the white panels), and 4) tephrochronology (Lava Creek B ash in well LBCC). The various approaches are in broad agreement with one another and confirm correlations among the wells based on sediment stacking patterns, geophysical log characteristics, and seismic stratigraphy observed in San Pedro Bay. 
Ground water is generally low in chlorides, even in the offshore region, but tend to be sodium bicarbonate rich (Land and others, 2004). Age is estimated at either around 2.0 or 2.6 Ma based on planktic foraminifera (CM5; Kucera and Kennett, 2000) and normal magnetic polarity (Cande and Kent, 1995).

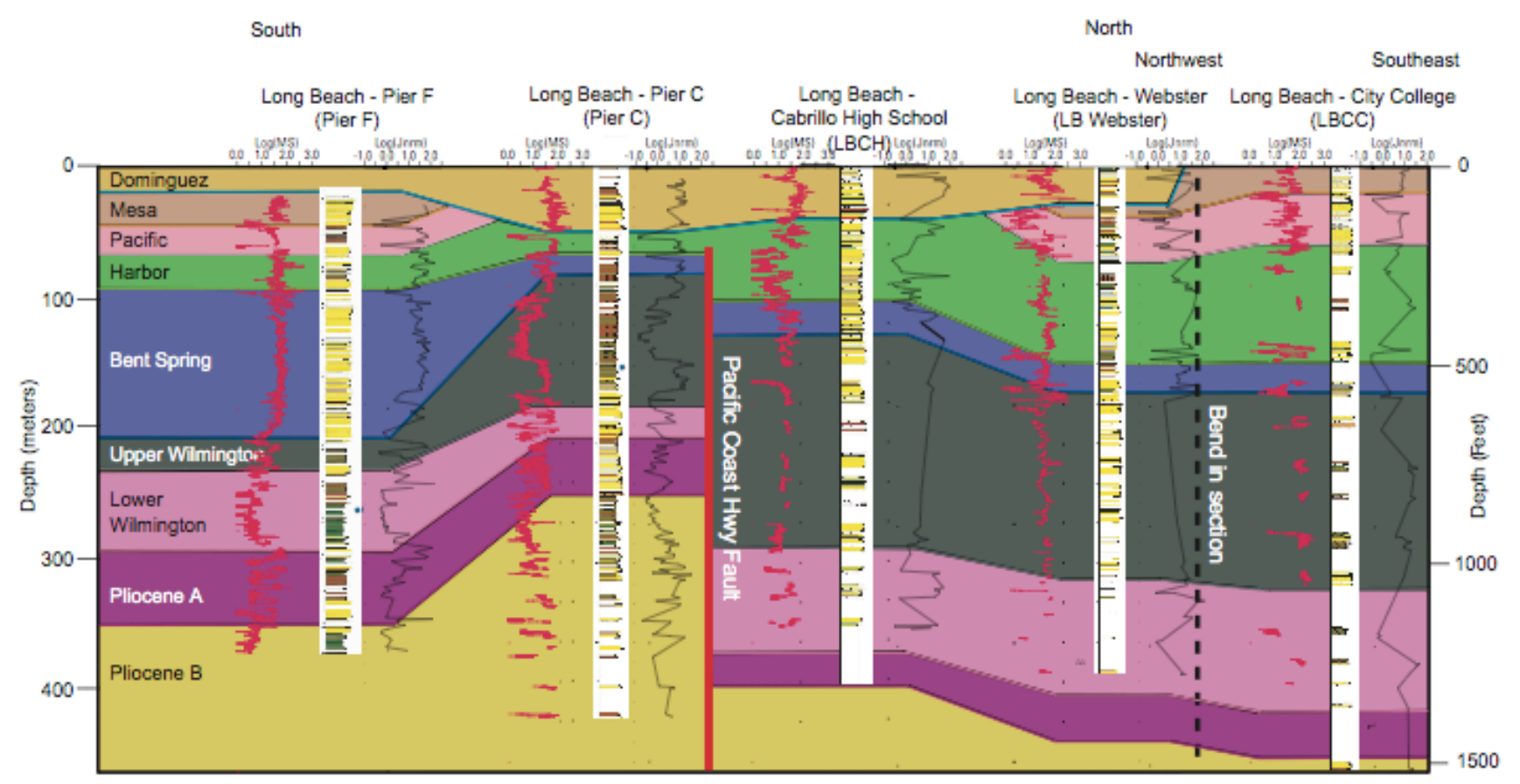

Figure 6. Magnetic intensity (black trace) and susceptibility (red trace) as measured from core samples. The Mesa-Pacific boundary is marked by low intensity in Pier F, LB Webster, and LBCC. The HarborBent Spring boundary has a low spike in all 5 wells. Upper Wilmington has a mid-section low in Pier $F$ and Pier C, but the few samples in the northern wells don't appear to show this. Pliocene A has increasing intensities from bottom to top and then a decrease in the Lower Wilmington in Pier $\mathrm{F}$ and Pier C. Magnetic susceptibility generally follows the intensity patterns. The negative inclination zones in the Pacific sequence correspond to sharp drops in susceptibility in Pier F, LB Webster, and LBCC. Transition from average values to low values going upward across the Harbor-Bent Spring boundary is also a prominent pattern. The consistent patterns in both magnetic susceptibility and intensity possibly reflect both temporal variations in the paleomagnetic field strength and sediment provenance and appear to prove useful for correlation.

\section{Pliocene A}

Pliocene $\mathrm{A}$ is a relatively thin ( $<50 \mathrm{~m}$ thick), generally sandy fining-upward sequence that has been previously assigned to both the San Pedro Formation (Poland and others, 1956) and the Pico Formation of Wright (1991). The base of the unit is very sharp contact where it overlies much finergrained Pliocene B. In the study areaa, the basal contact has both a distinctive electric log signature and is expressed in seismic reflection lines as a strong, regionally extensive reflector. Within the Wilmington oil field, this surface appears to correlate with horizon "FF" of Norton and Otott (1996). Microfauna suggest inner neritic deposition in water depths of $<30 \mathrm{~m}$. Zielbauer and others (1962) have assigned the Pico aquifer to this sequence north of the $\mathrm{PCH}$ fault, but south of the fault, wells that penetrate this unit have been assigned to the upper Silverado aquifer. LACDPW also assigns aquifers 
within this sequence to the Silverado south of the fault. Even in the offshore region, the pore fluids from this unit are relatively low in chloride (Land and others, 2004). Age estimates for the sequence fall within the constraints of Pliocene B, based on planktic microfaunal data and normal magnetic polarities.

\section{Lower Wilmington}

The lower Wilmington sequence is encountered in all of the reference core holes. In San Pedro Bay, the unit is typically sandy with a very sharp basal contact. The sands fine upward into muds with a series of coarsening upward sets and capped by silt. North of the PCH fault the sequence consists of basal blocky sands capped by fairly thick muds that coarsen upward. Faunal data indicate that the lower Wilmington was deposited in outer shelf to upper middle bathyal environments $(\sim 150-500 \mathrm{~m}$ water depth) north of the PCH fault. In San Pedro Bay, however, water depths were considerably deeper (500$1500 \mathrm{~m}$ ). The sequence appears to thicken slightly northward across the PCH fault. The unconformity marking the base of the lower Wilmington sequence represents a significant time hiatus. Microfossil data indicate a Pleistocene age, and normal magnetic polarities specify that the sequence is no older than $\sim 780 \mathrm{ky}$ (Cande and Kent, 1995). An early-mid-Pleistocene age for the unit is confirmed by the presence of a 15-cm thick bed of volcanic ash at a depth of 1241 feet (378 meters) in core hole LBCC. Chemical fingerprinting of the ash identifies it as Lava Creek "B", an ash erupted from the Yellowstone area and currently dated at $639+/-2 \mathrm{ka}$ by the Ar/Ar method (Lanphere and others, 2002).

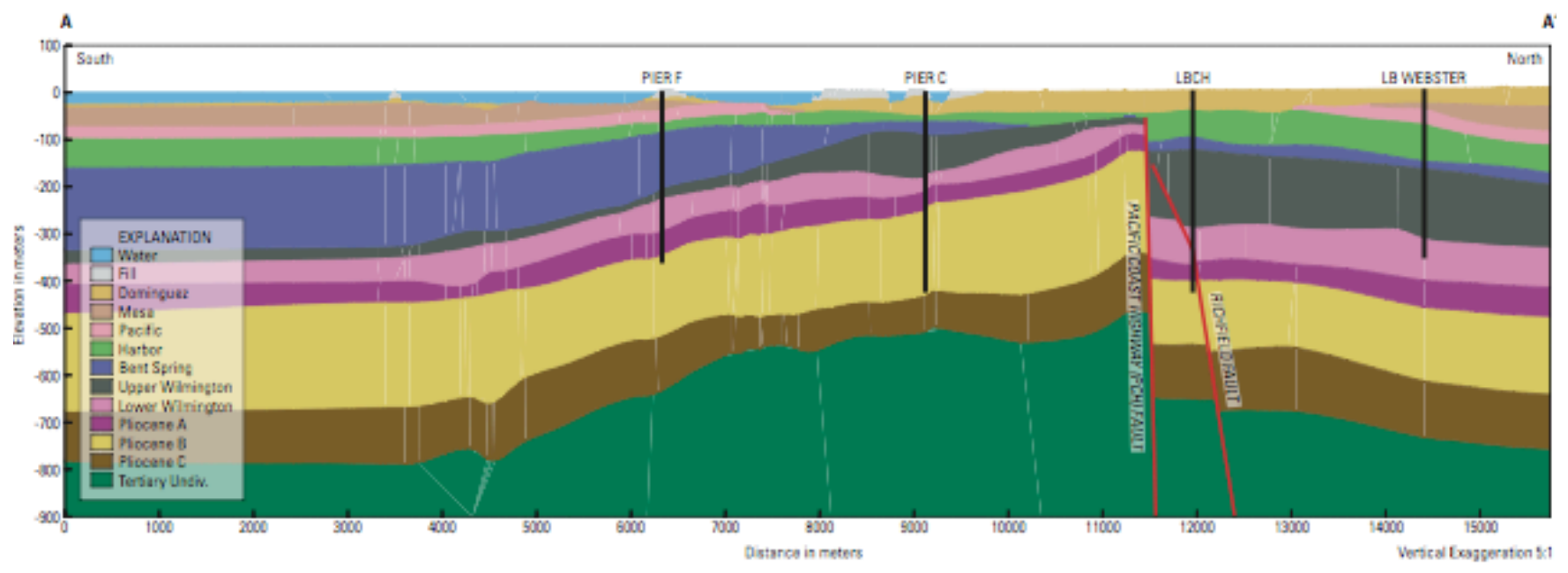

Figure 7. North-south section line (A- $\left.A^{\prime}\right)$ through the Dominguez Gap EarthVision model. Note the Dominguez (Gaspur) channel cutting and truncating Mesa and Pacific units in the northern part of the section. Change in apparent dip of the Richfield fault near well LBCH is due to slight change in strike of the section on either side of the borehole. Quaternary units typically thicken north of the Pacific Coast Highway fault. Maximum throw on the two faults approaches $200 \mathrm{~m}$ along this alignment (up to 250 meters to the east) and decreases in younger units. Displacement relations suggest that the faults became active in Lower Wilmington time and continued at least into Harbor time. Fault displacement is possible, but minimal, from Pacific time to present.

Aquifers within this sequence have been generally assigned to the lower San Pedro or Sunnyside systems (Reichard and others, 2003; California Department of Water Resources, 1961). South of the PCH fault, Zielbauer and others (1962) and LACDPW (2003) assign lower Wilmington aquifers to the Silverado. 


\section{Upper Wilmington}

Within the Dominguez gap region, the upper Wilmington sequence reflects a progradational, gradually coarsening upward package of shallow marine, deltaic, and locally, capping distributary delta or fluvial channel deposits. The sequence thickens significantly to the north and east of the PCH and Richfield faults (indicative of fault activity during upper Wilmington time) and its lithologic character changes substantially across the fault. Nearly everywhere in the study area, the basal portion of the upper Wilmington consists of marine sand deposited in water depths of probably not much greater than 50 meters. Where the unit is thickest (see the representative structure contour and isopach maps Figures 10 and 11), the marine sand is typically capped by a thick series of sands and gravelly sands that, in the LB Webster core hole, form large-scale tabular cross beds suggestive of a delta foreset complex. To the east in LBCC, the deltaic sands are intercalated with fine-grained beds, indicating a more distal part of the delta. Capping the sequence in the LB Webster, LBCH, and LBCC core holes is a fining-upward package consisting of a basal gravelly sand that may be of fluvial or distributary channel

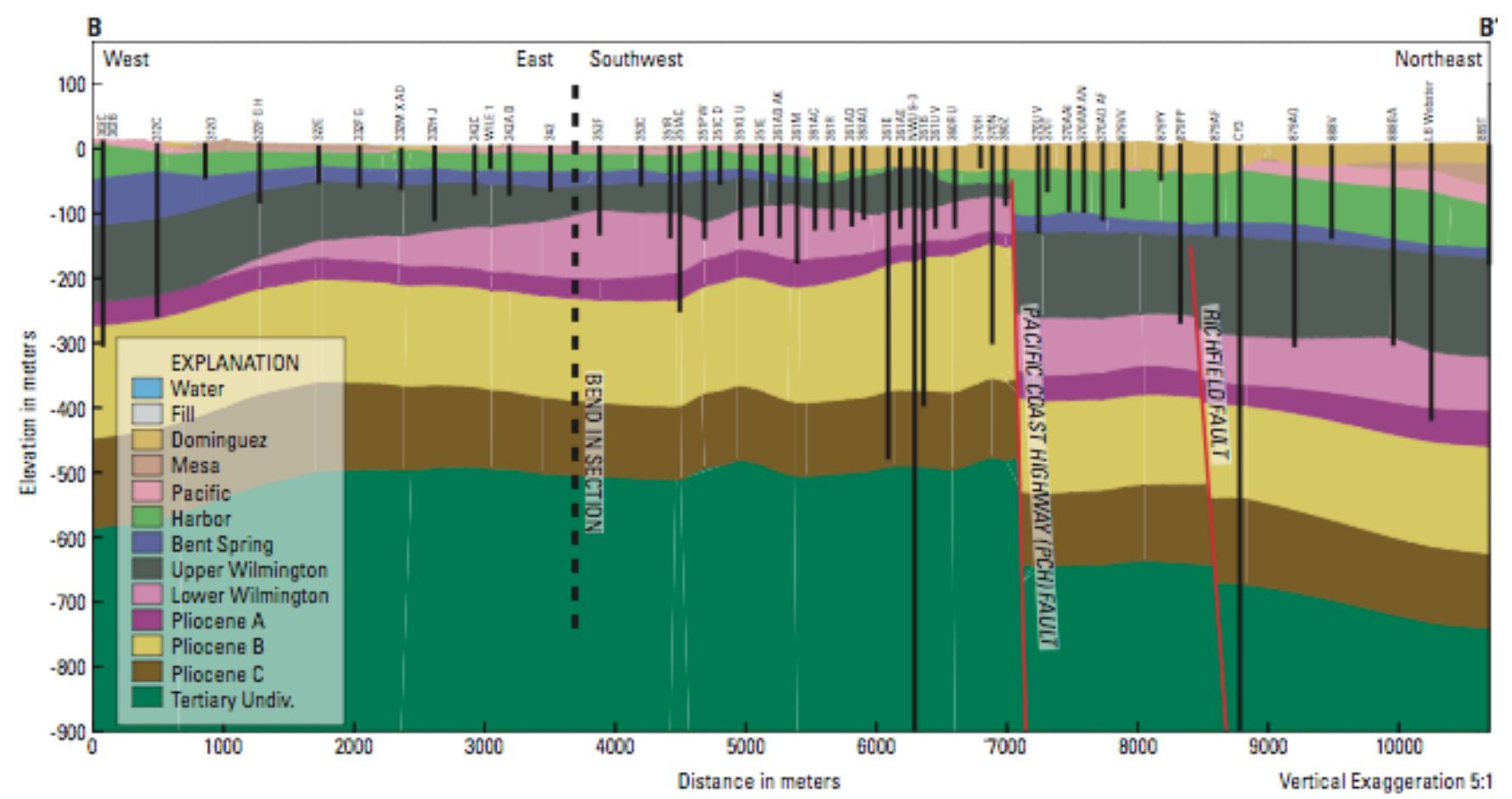

Figure 8. Section line (B-B') from the EarthVision model along the Dominguez Gap seawater intrusion barrier alignment. Note the Dominguez (Gaspur) channel cutting and truncating Mesa and Pacific units in the northern part of the section. The classic Silverado aquifer is confined to the Upper Wilmington sequence (dark grey) north of the Pacific Coast Highway fault. Ground water within the Silverado aquifer may be in communication with Pliocene $A$ and $B$ sequences resulting from juxtaposition of sandy facies across the fault. South of the Pacific Coast Highway fault much of the Upper Wilmington sequence is fine-grained. Sands of the Bent Spring sequence (blue) are quite thin across most of the barrier, but thicken significantly to the west into the Palos Verdes basin (well 302B). Sands of the Bent Spring sequence within the Palos Verdes basin correlate to the type San Pedro Sand of Woodring and others (1946) and comprise a southeast-prograding delta complex that is largely confined to this basin. 


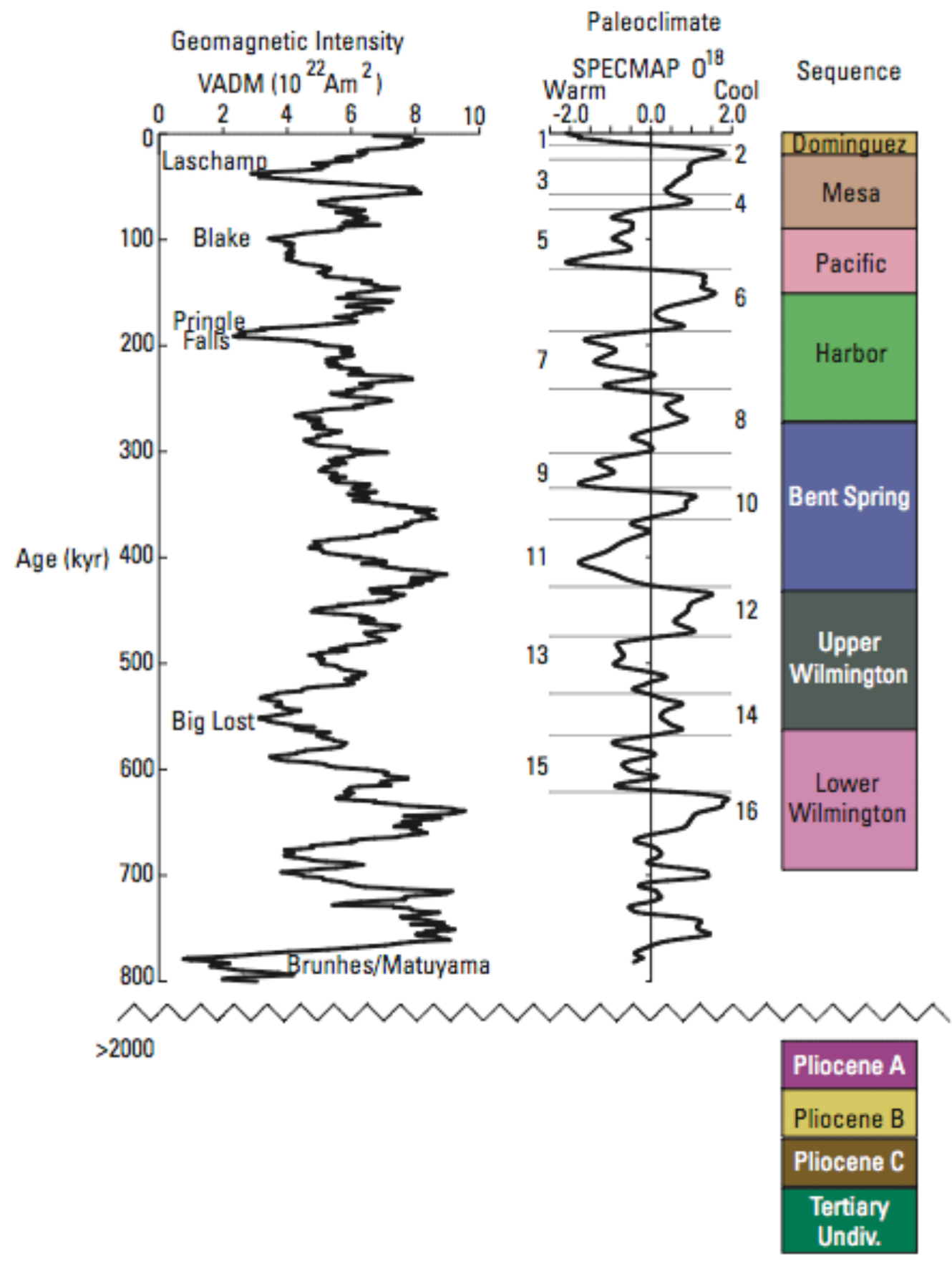

Figure 9. Age estimates of the Pleistocene sequences based on existing geochronologic data and correlation with the oxygen-isotope paleoclimate (curve by Imbrie and others, 1984, stage boundaries by Bassinot and others, 1994) and geomagnetic intensity (Guyodo and Valet, 1999) records. Named paleomagnetic events and numbered oxygen-isotope stages are shown. Sequence boundaries generally correspond to relative glacio-eustatic sea level low-stands (cool) whereas most sediment accumulates during sea level high-stands (warm) when the largest amount of sediment accommodation is available. 
Table 3. Correlation table relating sequence geology north of the PCH fault to formations and aquifer nomenclature in the Long Beach/Dominguez Gap region

\begin{tabular}{|c|c|c|c|c|c|c|c|}
\hline & \multirow{2}{*}{\multicolumn{4}{|c|}{ Aquifer/Aquifer System }} \\
\hline & & & & & & & \\
\hline 粮 & 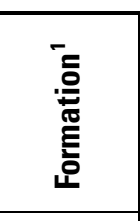 & $\begin{array}{c}\text { Sequence } \\
\text { (this report) }\end{array}$ & Age Estimate & $\begin{array}{c}\text { Zielbauer and } \\
\text { others } \\
\text { (1962) } \\
\end{array}$ & $\begin{array}{c}\text { LACDPW } \\
\text { (2003) }\end{array}$ & $\begin{array}{l}\text { California } \\
\text { Dept. of } \\
\text { Water } \\
\text { Resources } \\
\text { (1961) } \\
\end{array}$ & $\begin{array}{c}\text { Reichard } \\
\text { and others } \\
\text { (2003) }\end{array}$ \\
\hline 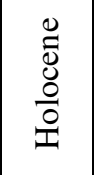 & 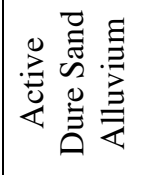 & Dominguez & $<15 \mathrm{ka}$ & Gaspur & Gaspur & Gaspur & Recent \\
\hline \multirow{2}{*}{ 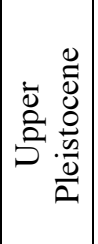 } & \multirow{2}{*}{ 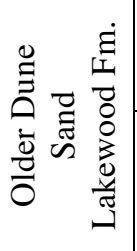 } & Mesa & $\begin{array}{l}\text { Latest Pleistocene } \\
\quad(\sim 30-80 \mathrm{ka})\end{array}$ & \multirow[b]{2}{*}{$200 \mathrm{ft}$ sand } & $\begin{array}{l}\text { Gage } 1 \\
\text { and } 2\end{array}$ & \multirow[b]{2}{*}{ Gage } & \multirow[b]{2}{*}{ Lakewood } \\
\hline & & Pacific & $\begin{array}{l}\text { Early }{ }^{18} \mathrm{O} \text { stage } 5 \\
\quad(110-130 \mathrm{ka})\end{array}$ & & $\begin{array}{c}\text { Gage } 3 \\
\text { and } 4\end{array}$ & & \\
\hline \multirow{4}{*}{ 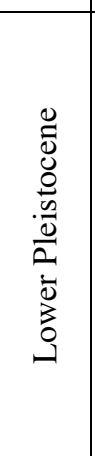 } & \multirow{4}{*}{ 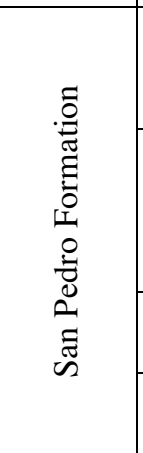 } & Harbor $^{2}$ & $\begin{array}{c}\text { Constrained between }{ }^{18} \mathrm{O} \\
\text { stage } 5 \text { and } 9 \\
(\sim 160-300 \mathrm{ka})\end{array}$ & $\begin{array}{l}400 \mathrm{ft} \text { gravel; } \\
200 \mathrm{ft} \text { sand }\end{array}$ & $\begin{array}{l}\text { Lynwood, } \\
\text { Gage } 4\end{array}$ & Lynwood & \multirow{3}{*}{$\begin{array}{l}\text { Upper San } \\
\text { Pedro }\end{array}$} \\
\hline & & Bent Spring & $\begin{array}{l}{ }^{18} \mathrm{O} \text { stage } 9-11 \\
(\sim 300-450 \mathrm{ka})\end{array}$ & $\begin{array}{c}\text { Upper } \\
\text { Silverado, } \\
\text { some Lower } \\
\text { Silverado }\end{array}$ & \multirow[t]{2}{*}{ Silverado } & \multirow[t]{2}{*}{ Silverado } & \\
\hline & & $\begin{array}{c}\text { Upper } \\
\text { Wilmington }\end{array}$ & $\begin{array}{l}{ }^{8} \mathrm{O} \text { stage } 12-14 \\
(\sim 475-580 \mathrm{ka})\end{array}$ & $\begin{array}{c}\text { Lower } \\
\text { Silverado }\end{array}$ & & & \\
\hline & & $\begin{array}{c}\text { Lower } \\
\text { Wilmington }\end{array}$ & $\begin{array}{l}{ }^{8} \mathrm{O} \text { stage } 15-17+ \\
(\sim 580-<780 \mathrm{ka})\end{array}$ & \multirow{3}{*}{ Pico } & \multirow{3}{*}{$\begin{array}{c}\text { Not } \\
\text { reported }\end{array}$} & Sunnyside ${ }^{3}$ & \multirow[b]{2}{*}{$\begin{array}{c}\text { Lower San } \\
\text { Pedro }\end{array}$} \\
\hline \multirow{3}{*}{ 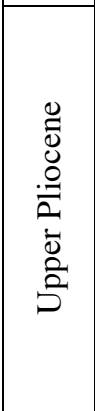 } & \multirow{3}{*}{ 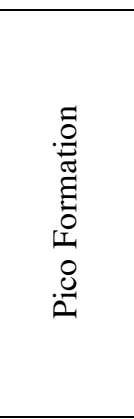 } & Pliocene A & $\begin{array}{l}\sim 2.0 \mathrm{Ma} \text { or }>2.6 \mathrm{Ma} \\
\text { from magnetic polarity } \\
\text { and paleontology }\end{array}$ & & & \multirow{2}{*}{ Pico } & \\
\hline & & Pliocene B & $\begin{array}{l}\sim 2.0 \mathrm{Ma} \text { or }>2.6 \mathrm{Ma} \\
\text { from magnetic polarity } \\
\text { and paleontology }\end{array}$ & & & & Pico \\
\hline & & Pliocene C & $\begin{array}{c}\text { >2.6 Ma from magnetic } \\
\text { polarity and } \\
\text { paleontology }\end{array}$ & $\begin{array}{c}\text { not } \\
\text { penetrated } \\
\text { by water } \\
\text { wells }\end{array}$ & $\begin{array}{c}\text { not } \\
\text { penetrated } \\
\text { by water } \\
\text { wells }\end{array}$ & $\begin{array}{c}\text { not } \\
\text { penetrated } \\
\text { by water } \\
\text { wells } \\
\end{array}$ & $\begin{array}{c}\text { not } \\
\text { penetrated } \\
\text { by water } \\
\text { wells }\end{array}$ \\
\hline
\end{tabular}

${ }^{1}$ Series and formation designation from California Dept. of Water Resources (1961).

${ }^{2}$ Lowermost part of Harbor sequence is probably correlative with the uppermost San Pedro Sand of Woodring and others (1946).

${ }^{3}$ In this region, the section that is generally correlative with the Lower Wilmington sequence is not designated as an aquifer by California Dept. of Water Resources (1961), but stratigraphically would correspond with the Sunnyside. 
Table 4. Correlation table relating sequence geology south of the PCH fault to formations and aquifer nomenclature in the Long Beach/Dominguez Gap region

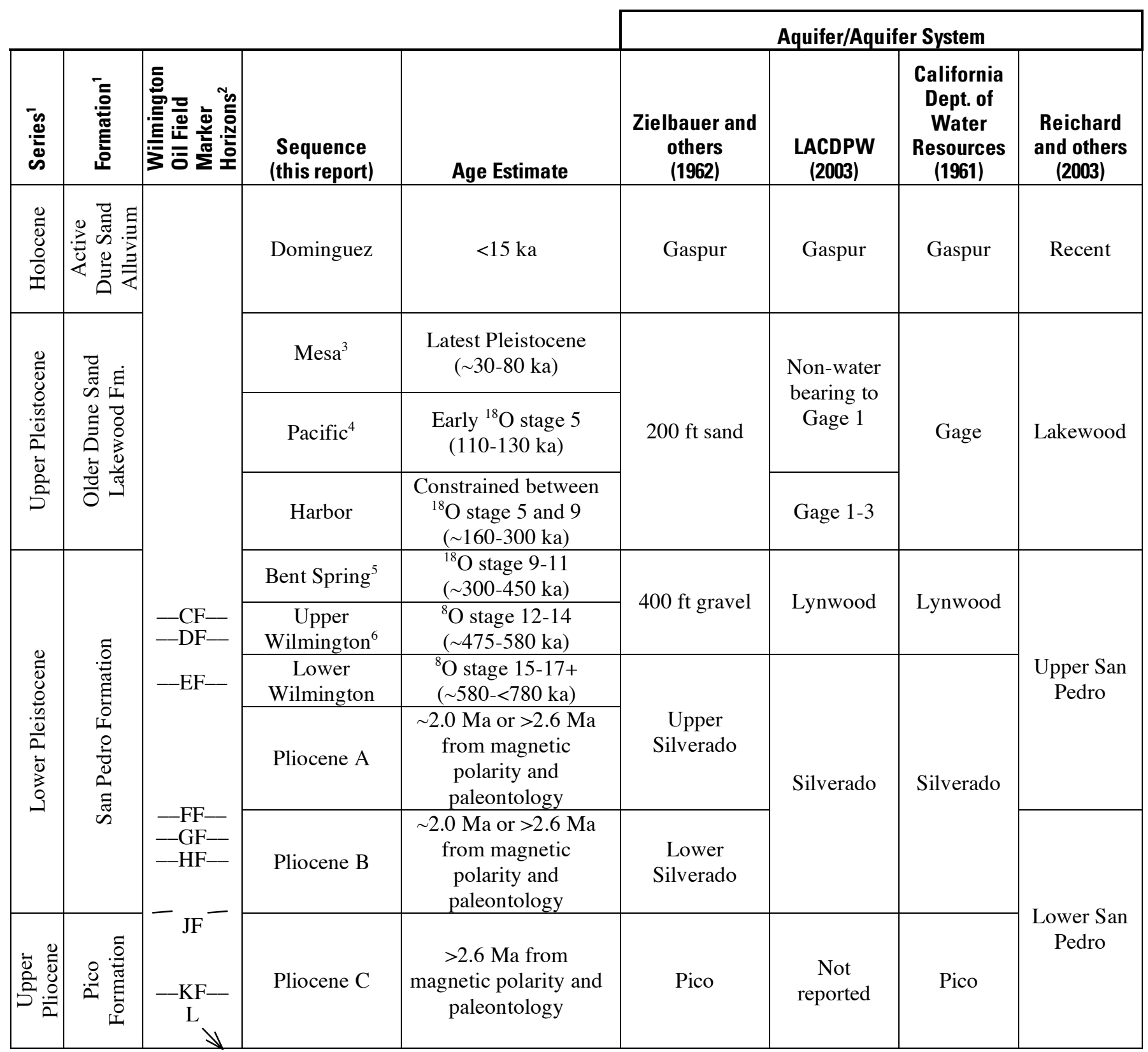

${ }^{1}$ Series and formation designation from California Dept. of Water Resources (1961).

${ }^{2}$ From Norton and Otott (1996) and Donald Clarke, written communication (2006). Table shows approximate location of the markers within each sequence.

${ }^{3}$ Mesa sequence is thin and largely non-water bearing south of the PCH fault. It is in part correlative with Terrace 1 in San Pedro. (Woodring and others, 1946). 
${ }^{4}$ At the western end of the Dominguez barrier, within the Palos Verdes basin, the Lynwood/400 $\mathrm{ft}$ gravel falls within the Pacific sequence. It is correlative with Terrace 2 and parts of Terrace 1 in San Pedro (Woodring and others, 1946).

${ }^{5}$ Bent Spring sequence is generally thin and fine grained south of the $\mathrm{PCH}$ fault except at the extreme western end of the Dominguez barrier and offshore in the Palos Verdes Basin. It is correlative with the type San Pedro Sand and Timms Pt. Silt in San Pedro (Woodring and others, 1946).

${ }^{6}$ The Upper Wilmington sequence is generally fine-grained and non-water bearing south of the PCH fault

origin. The thick accumulation of coarse-grained sediment that occurs adjacent to and north of the PCH fault comprises the classic Silverado aquifer of Poland and others (1956). Our model indicates that the southern margin of this aquifer terminates against the north side of the PCH fault system.

To the south of the fault, the sequence is generally fine-grained with a few thin sandy units that have been classified as "400 ft gravel" or Lynwood aquifer by Zielbauer and others (1962) and LACDPW (2003). In the Long Beach harbor area, based on the Pier C and Pier F core holes, the sequence is composed principally of muds that gradually thin offshore into San Pedro Bay.

In Pier C and Pier F, pore fluids at the top of the upper Wilmington sequence contain significant chloride, but chloride levels decrease rapidly with depth (Land and others, 2004). North of the fault, there is evidence for incipient invasion of high-chloride waters into the uppermost part of the upper Wilmington sequence (lower Silverado aquifer) in core hole LBCH. Chloride concentrations of $\sim 1400$ $\mathrm{mg} / \mathrm{l}$ are observed within the sequence to a depth of 440 feet (134 meters; Figure 12). Further to the north, in LB Webster, there is not yet evidence for chloride invasion into the sequence.

There is a suggestion that chloride invasion into the upper Wilmington at $\mathrm{LBCH}$ may have occurred sometime since 1992. LACDPW well 370AH AJ, located only about 100 meters north of $\mathrm{LBCH}$, has resistivity $\log$ character that is much different than that for $\mathrm{LBCH}$ between the depths of 350 and 408 feet (106 to 124 meters). The log from 370AH AJ, which was run in Oct. 1992, suggests that more resistive pore fluids were present in the interval at that time (Figure 12).

Most of the upper Wilmington sequence probably was deposited during a single sea level high stand - most likely ${ }^{18} \mathrm{O}$ stage 14-13 transgression (474-568 ka, Bassinot and others, 1994). A sediment thermoluminescence date of $425 \pm 55 \mathrm{ka}$ comes from near the top of the sequence in Pier C. Reversed or low angle magnetic inclinations are also observed within the mid-lower portion of the upper Wilmington in three core holes. This magnetic anomaly may correlate with the Big Lost polarity event. Age estimates for this event range from $\sim 525-550 \mathrm{ka}$ (Guyodo and Valet, 1999) to 565-579 ka (Champion and others, 1988; Hoffman and Singer, 2004).

\section{Bent Spring}

The Bent Spring sequence is primarily a sandy unit of marine origin. Onshore, the sequence consists of a fairly thin ( 20 m thick), typically fining-upward deposit that likely formed on the shelf and/or upper slope. In the western part of San Pedro Bay, seismic data shows that more than 200 meters of Bent Spring sediment occurs within a NW-SE-trending trough, of probable structural origin, that is located along the NE flank of the Palos Verdes fault. This trough is also revealed as a series of lows in the residual gravity field (Figure 13b) that extends onshore as well. While the Bent Spring sequence thickens considerably in this trough, underlying sequences do not; thus the present basin did not begin to form until, or just prior to, Bent Spring time. We use the term Palos Verdes basin to describe this 


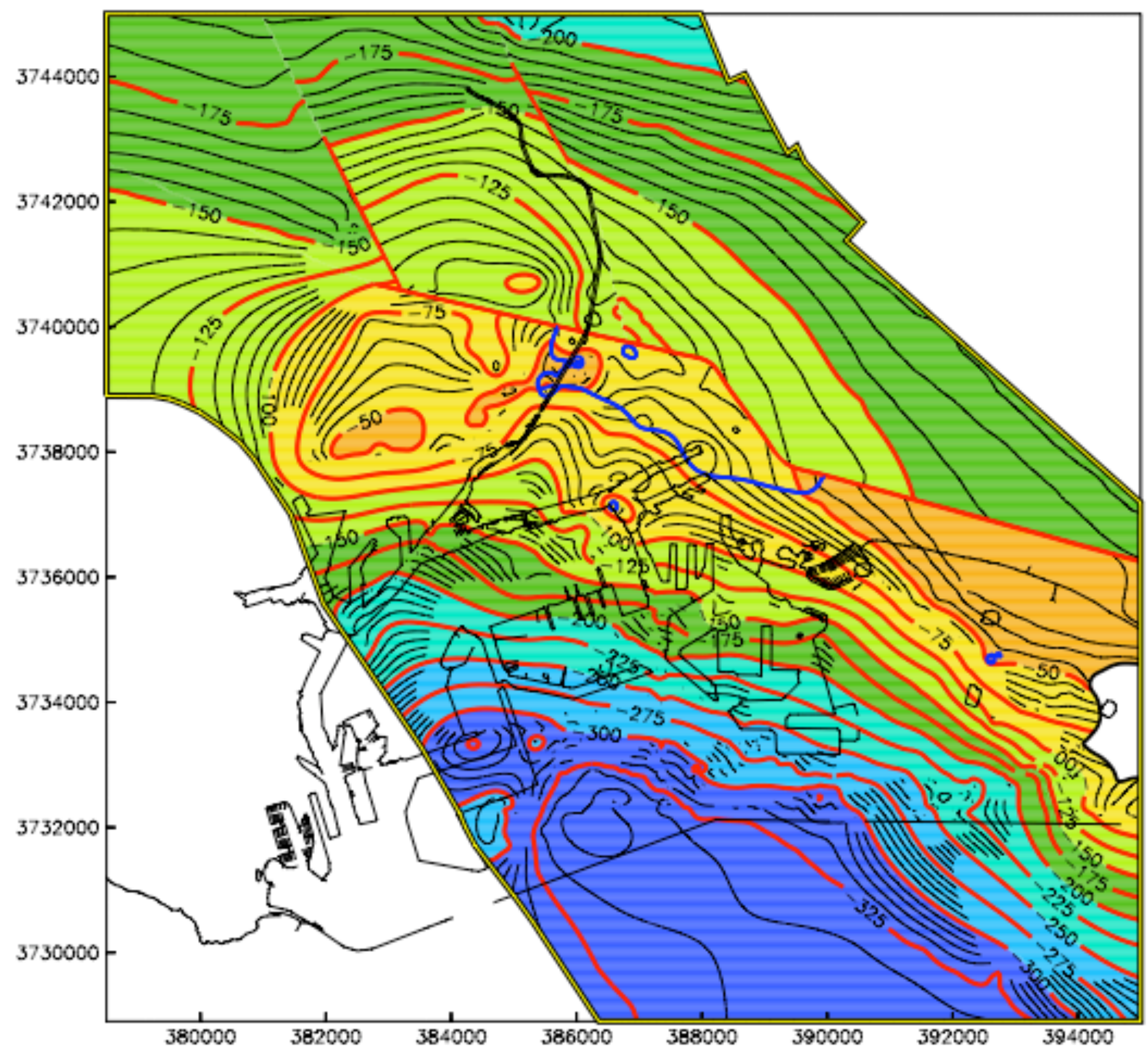

Figure 10. Structure contour map on the top of the Upper Wilmington sequence. Contour interval is $5 \mathrm{~m}$, altitude in NAVD88 meters; axes give UTM (Zone 11, NAD83) coordinates in meters. Note how the surface rises over the Wilmington antic line and is down dropped north of the Pacific Coast Highway fault system. The classic Silverado aquifer of Poland and others (1956) is largely contained within the Upper Wilmington sequence in the down dropped block north of the Pacific Coast Highway fault. A north-northwest trending synclinal trough is expressed in the contours in San Pedro Bay, which reflects subsequent warping of the unit during formation of the Palos Verdes basin. Blue lines mark regions where the overlying Bent Spring sequence is missing and therefore where the top of the Upper Wilmington has been eroded. 


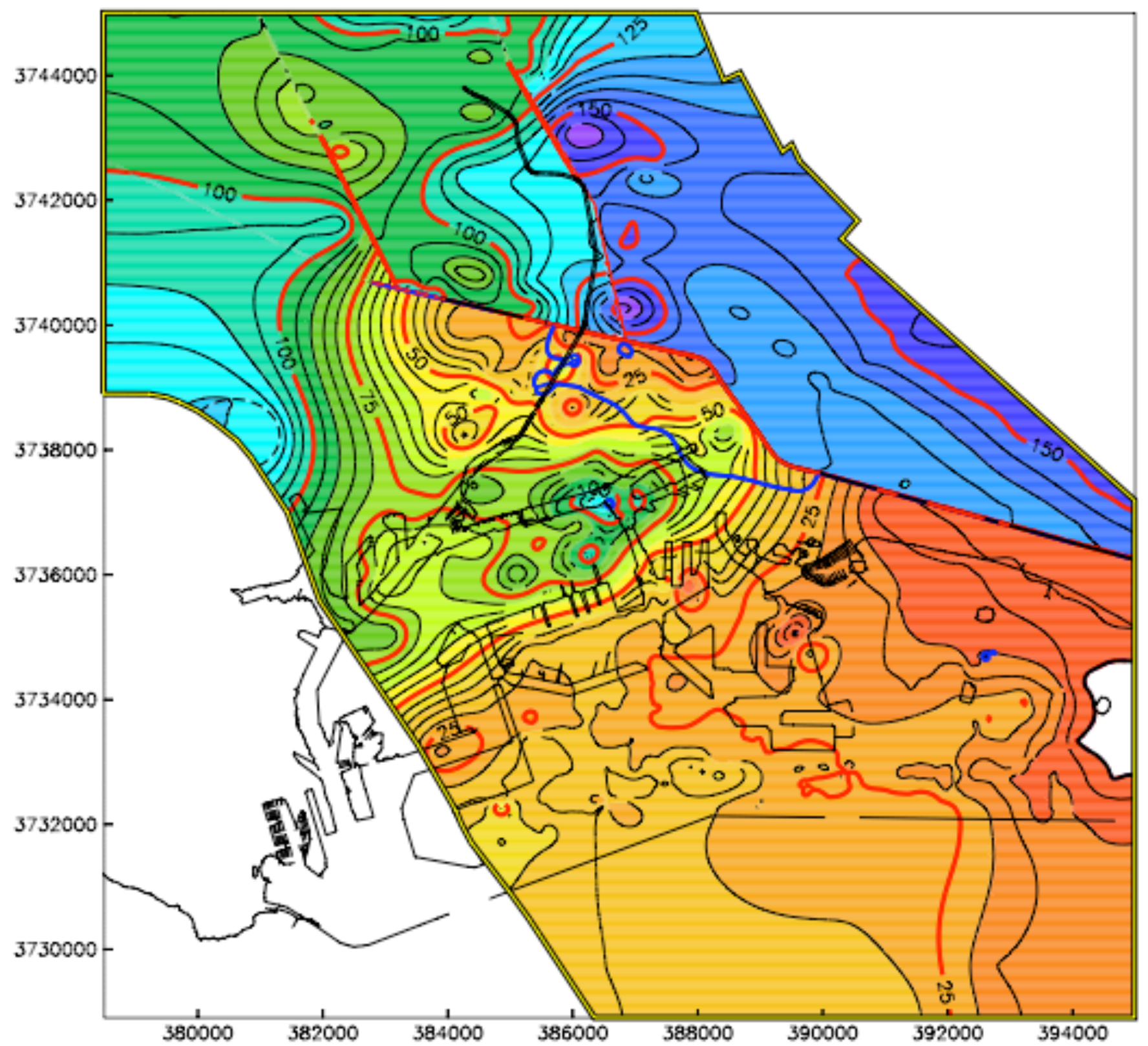

Figure 11. Isochore (vertical thickness) map for the Upper Wilmington sequence. Contour interval $5 \mathrm{~m}$; axes give UTM (Zone 11, NAD83) coordinates in meters. The unit is generally thin along the crest of the Wilmington anticline and south of the Pacific Coast Highway fault, but is significantly thicker northeast of the Pacific Coast Highway and Richfield faults where the classic Silverado aquifer (Poland and others, 1956) is confined. The unit is relatively thin in San Pedro Bay and does not reflect the northwest trending trough that is largely filled by thick, sandy, deltaic deposits of the Bent Spring sequence (classic San Pedro sand of Woodring and others, 1946). This relation suggests that most Upper Wilmington deposition predates formation of the Palos Verdes basin. Blue lines mark regions where the model predicts that the overlying Bent Spring sequence is missing and therefore where the top of the Upper Wilmington has been eroded. Dashed lines mark regions where the model predicts the underlying Lower Wilmington sequence has pinched out and where the Upper Wilmington sequence directly overlies Pliocene A. 


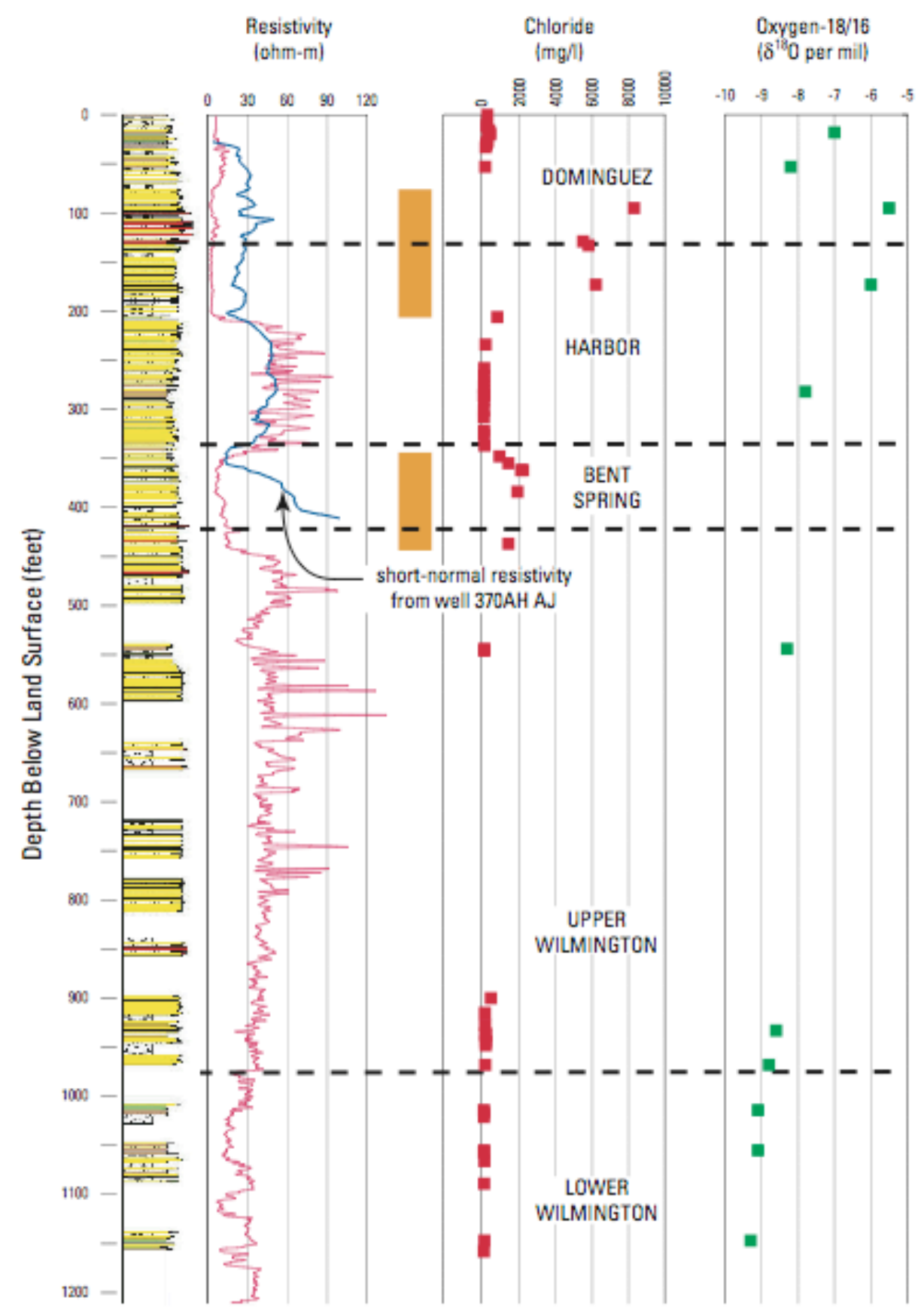

Figure 12. Chloride concentrations and oxygen 18/16 ratios from the LBCH core hole. Pore fluids were extracted from the cores soon after they were retrieved. Two zones of groundwater show evidence of possible seawater intrusion (orange bars) as evidenced by high $\mathrm{Cl}$ and suppressed array induction resistivity (red trace). The highest $\mathrm{Cl}$ levels occur at the base of the Dominguez sequence (Gaspur aquifer) and upper part of the Harbor (Gage aquifer). Significant Cl concentrations (1400- $2200 \mathrm{mg} / \mathrm{l}$ ) also occur in the Bent Spring (Upper Silverado aquifer of Zielbauer and others, 1962)) and Upper Wilmington (Lower Silverado aquifer of Zielbauer and others, 1962) sequences to a depth of $440 \mathrm{ft}(134 \mathrm{~m})$. From the resistivity log of nearby well 370AH AJ (blue trace), it appears that $\mathrm{Cl}$ has impacted the deeper zone since well 370AH AJ was logged in Oct. 1992. 
young feature. Within the Palos Verdes basin, based on the Pier F core hole, the Bent Spring of the inner harbor area consists primarily of sand. Seismic data reveal the presence of SE-dipping clinoforms and probable distributary channels, indicating that the Bent Spring comprises a delta complex that prograded NW to SE along the basin axis.

The stratigraphic position and character of the Bent Spring sequence in San Pedro Bay indicates that it is correlative with the San Pedro Sand and Timms Point Silt of Woodring and others (1946) that crops out in San Pedro and along the northeast flank of the Palos Verdes Hills. Poland and others (1956) have proposed that these units are correlative with the San Pedro Formation throughout the Los Angeles basin and that the thick "San Pedro Sand" facies of this formation is equivalent to the type Silverado aquifer in Long Beach. Although the type Silverado and San Pedro Sand have similar character and both contain deltaic facies, our study indicates that the type San Pedro Sand of Woodring and others (1946), as part of the Bent Spring sequence, is a distinct, younger, deposit.

Zielbauer and others (1962) considers sands of the Bent Spring sequence within the Palos Verdes basin region south of the PCH fault to be part of the upper Silverado aquifer. Within Pier F, pore fluids have very high salinities approaching that of natural seawater (Land and others, 2004). Several boreholes drilled by Caltrans and logged by the USGS near Vincent Thomas Bridge, have electric log characters that also suggest high pore fluid salinities within sandy portions of the Bent Spring.

North of the PCH fault, sands of this sequence are considered by Zielbauer and others (1962) and LACDPW (2003) to be part of the Silverado aquifer. In core hole LBCH, chloride concentrations as high as $2200 \mathrm{mg} / \mathrm{l}$ have been measured in the sequence (Figure 12). This zone of invasion is the same one that also impacts the upper Wilmington sequence. Further north, at LB Webster, Bent Spring pore fluids have chloride concentrations around $100 \mathrm{mg} / \mathrm{l}$ (Land and others, 2004).

Bent Spring deposition probably occurred during ${ }^{18} \mathrm{O}$ stage 9 and/or 11 (301 to $427 \mathrm{ka}$, Bassinot and others, 1994) based on bracketing ages in other sequences. A sediment thermoluminescence date of $309 \pm 24$ ka comes from the abbreviated section of Bent Spring in Pier C, but shows evidence of saturation, so the date may reflect only a minimum age.

\section{Harbor}

The Harbor sequence is an areally extensive series of deposits that record a coastal progradation and encompass a number of sedimentary environments ranging from the marine shelf to coastal beach, tidal flats, lagoons, and possibly even fluvial channels and floodplains. In San Pedro Bay, the sequence has a gravel lag at its base that commonly truncates underlying units. Seismically, numerous parallel reflectors characterize the sequence. While the unit is lithologically variable, the Harbor sequence, especially north of the $\mathrm{PCH}$ fault, commonly consists of basal sand or gravels that grade rapidly into marine muds, and then gradually coarsens upward into a series of interbedded sands and silty sands. The sequence is generally thin just south of the $\mathrm{PCH}$ fault, but thickens north of the fault and also gradually thickens offshore into the Palos Verdes basin.

Typically, the basal sand of the Harbor sequence and the coarse grained beds of the upper Harbor have been considered as different aquifers by Zielbauer and others (1962) and LACDPW (2003) north of the PCH fault. The lower sand is typically considered as part of the " $400 \mathrm{ft}$ gravel"/Lynwood aquifer whereas the upper sands generally have been classified into the "200 foot sand"/Gage 4 aquifers. South of the fault, the Harbor sequence includes the "200 foot sand" of Zielbauer and others (1962) and Gage 1-3 units of LACDPW (2003).

Water quality within the Harbor sequence in the Dominguez barrier region is quite variable as well, ranging from near-seawater salinities in the offshore region to fresh water inland. South of the $\mathrm{PCH}$ fault, especially where the Harbor is in direct contact with the Dominguez sequence, the unit is 
typically invaded by seawater. North of the PCH fault, portions of the Harbor beneath the Dominguez sequence are invaded by high-chloride water at least as far north as LB Webster, where pore fluids within the unit have a chloride concentrations as high as $2900 \mathrm{mg} / \mathrm{l}$ (Land and others, 2004).

We have no direct dates on the Harbor sequence in the study area, but its age is constrained between ${ }^{18} \mathrm{O}$ stages 5 and 9 (127 - $301 \mathrm{ka}$, Bassinot and others, 1994). Low paleomagnetic inclinations observed near the base of the Harbor sequence in the Pier F and LBCH core holes may result from the Pringle Falls polarity event, which dates at around $200 \mathrm{ka}$ (Guyodo and Valet, 1999).

\section{Pacific}

The Pacific sequence is a relatively thin, shallow-water marine to paralic unit that consists of a basal inner neritic to intertidal marine sand that fines upward into interbedded tidal flat, tidal channel, fluvial channel and overbank deposits. In San Pedro Bay, the sequence is characterized by parallel reflectors with a basal reflector that is very well defined on the shelf but subtler in the harbor area. Our model suggests that the unit may be exposed at the sea floor within dredged channels in the harbor east of the Los Angeles River. The unit thins as it comes onshore over the crest of the Wilmington anticline and is truncated near the coastline by the Dominguez sequence. It reappears again beneath the Dominguez sequence north of Sepulveda/Willow Sts. in the vicinity of the Dominguez barrier (see Figure 7).

Where present, the Pacific sequence is generally considered as part of the "200 foot sand" or Gage aquifers by Zielbauer and others (1962) and LACDPW (2003). North of the PCH fault the Pacific sequence comprises the Gage 3 and 4 aquifers of LACDPW (2003), but contains the Gage 1 south of the fault.

The Pacific sequence is the best dated of the sequences in the region, and resulted from a marine high-stand progradation during early ${ }^{18} \mathrm{O}$ stage 5 (97 - $122 \mathrm{ka}$, Bassinot and others, 1994). In all of the core holes where the Pacific sequence is present (LB Webster, Pier F, and LBCC), low or reversed paleomagnetic inclinations are observed that almost certainly reflect the Blake polarity event. This event has been correlated to the ${ }^{18} \mathrm{O}$ stage 5e-5d transition at about $115 \mathrm{ka}$ (Tucholka and others, 1987; Guyodo and Valet, 1999). Several sediment luminescence dates from LB Webster and Pier F near the Blake event give similar ages (Figure 5).

\section{Mesa}

The Mesa sequence is very similar in character to the underlying Pacific sequence and reflects a prograding shoreline. In San Pedro Bay, as observed in the Pier F core hole, the sequence generally consists of a basal marine gravel/sand lag overlain by fine sand and silt and then a series of sandy, coarsening upward packages of shallow marine origin. On land the unit generally fines upward and may be dominantly of fluvial or marginal marine origin and the basal sands likely reflect fluvial channel, tidal channel deposits, and beach deposits. The sequence is exposed at the surface in the Torrance and Long Beach plains and its surface lies within $2 \mathrm{~m}$ of the sea floor east of the Los Angeles River channel (Figure 1). In San Pedro Bay, the reflector that marks the base of the Mesa sequence is well defined and regionally correlative.

Like the Pacific sequence, the Mesa is locally removed by the Dominguez sequence and is not present beneath the Dominguez from just north of the Pier F core hole to just south of LB Webster, where a thin slice of the Mesa is preserved (Figure 7). Where present north of the PCH fault, the Mesa sequence contains the "200 foot sand" (Zielbauer and others, 1962) and Gage 1 and 2 aquifers (LACDPW, 2003). 
The Mesa sequence is latest Pleistocene in age. Basal marine facies of the sequence may be as old as ${ }^{18} \mathrm{O}$ stage 5 a (isotopic event 5.1 at $79 \mathrm{ka}$, Bassinot and others, 1994) and thus may be correlative with the type Palos Verdes Sand of Woodring and others (1946) exposed on the low (first) terrace in San Pedro. Sediment luminescence dates of around $30 \mathrm{ka}$ were obtained from the Mesa sequence in Pier $\mathrm{F}$, but may be minimum ages. In core hole LBCC, a low magnetic inclination near the top of the sequence may be the Laschamp polarity event, dated at around $40 \mathrm{ka}$ (Guyodo and Valet, 1999).

\section{Dominguez}

The Dominguez sequence is the result of deposition that occurred in response to worldwide climate change that initiated the Holocene epoch. During the last glaciation, which reached its peak about $17 \mathrm{ky}$ ago (Bassinot and others 1994), sea level was on the order of $120 \mathrm{~m}$ below present. As a result, the Los Angeles River downcut approximately 40-50 meters below present ground surface in the region and locally removed parts of the older sequences. As the Pleistocene climate ameliorated, vegetation assemblages in the mountains ringing the Los Angeles basin shifted from conifer-dominated to the oak-grassland-chaparral-dominated sclerophyllous vegetation common on today's hillslopes in central and southern California (Bull, 1991). Consequently, the thick mantle of weathered rock and soil materials that accumulated on the hillslopes under coniferous forest conditions became unstable as the conifers died out and were replaced by oaks. Wildland fires also became more frequent, further serving to de-stabilize the landscape and expose the soil mantle to erosional processes. Resultant erosion caused mountain streams to aggrade rapidly as fill terraces were deposited. Subsequent erosion of the fill terraces progressively moved sediment downstream out of the canyons and onto the coastal plain, ultimately filling the eroded channels near the current coastline. In addition to the upland stream response, the Pleistocene-Holocene climate change also caused a rapid rise in sea level that allowed shallow marine and paralic deposits to be interbedded with the fluvial sediment in the backfilled channel areas.

In the study area, the basal part of the Dominguez sequence consists of 2 to 3 gravel packages of fluvial origin that fine upward into marginal marine and estuarine deposits. As the Los Angeles River continued to build out to the present coastline, the estuarine deposits were overlain by generally finegrained floodplain muds and fine sands, localized lagoonal and lacustrine sediment, and in the present offshore, shallow marine sediment.

The basal gravel beds comprise the Gaspur aquifer of Zielbauer and others (1962) and LACDPW (2003). Large areas of this aquifer are significantly invaded by seawater. The sequence is in direct contact with the seafloor in San Pedro Bay, and in Pier F, pore fluids in the Dominguez sequence have chloride concentrations comparable to that of seawater (Land and others, 2004). Inland, chloride concentrations in the Gaspur aquifer at $\mathrm{LBCH}$ reach a maximum of $8300 \mathrm{mg} / \mathrm{l}$, and fall to below 700 $\mathrm{mg} / \mathrm{l}$ in LB Webster (Land and others, 2004).

Age of the base of the Dominguez sequence probably coincides with major vegetation changes that allowed for the release of sediment into the river system around $13 \mathrm{ky}$ ago (Weldon, 1986, 1989). A tidal marsh peat deposit approximately 30 feet $(10 \mathrm{~m})$ deep in LB Webster dates to approximately 1,800 years based on radiocarbon and luminescence ages. 


\section{Geologic Structures}

Nearly all of the sequences identified in this study have been subject to tectonic deformation resulting from folding and faulting that initiated in the Pleistocene and may be continuing to the present day. As a result of this deformation, several of the sequences have been eroded such that their finegrained capping deposits, which serve as barriers to vertical ground-water flow, have been locally removed - thus disrupting the lateral continuity of these ground water barriers. Faulting also appears to disrupt all of the sequences up through at least the Harbor sequence. The faulting may produce barriers to lateral flow in some areas, or flow-through where aquifers within different sequences are juxtaposed.

A prominent first order feature in the region is broad anticlinal folding along a W-NW trend associated with the Wilmington anticline (Figure 13). The Wilmington anticline is a well-known, extensively studied structure that serves as a trap for the largest oil field in the Los Angeles basin (Clarke and Phillips, 2003). Folding along the anticline was most extensive during early Pliocene (Repetto of Wright, 1991) time. The top of the Repetto in the Wilmington oil field (which appears to correspond to the base of Pliocene $\mathrm{C}$ ) is marked by a strong angular discordance that suggests cessation of folding at about that time (Mayuga, 1970). However, Wright (1991) points out that the absence of lower Pico and some upper Repetto sediment along the fold crest suggests that growth of the fold extended into the late Pliocene. A suggestion of minor thickening of the Pliocene $\mathrm{C}$ and $\mathrm{B}$ sequences north of Pier $\mathrm{C}$ (Figures 7 and 8) may support a small amount of continued growth of the Wilmington fold in the late Pliocene.

The long hiatus associated with the boundary between the Pliocene A and lower Wilmington sequences, without clear evidence of an angular unconformity between the two sequences, suggests that fold growth essentially stopped in the latest Pliocene and early Pleistocene, between approximately 2 and 0.78 million years ago. As a result of our current work, we now recognize a more recent phase of folding that began after this hiatus. This new folding episode has a strike that appears similar to that of the older Wilmington trend, but the young axial surface appears to be displaced more than $2 \mathrm{~km}$ to the north. Whereas the old Wilmington fold crest occurs approximately beneath the Pier C core hole (as suggested by a general flattening at the top of the Tertiary undifferentiated unit in section A-A' relative to the younger units, Figure 7), the new fold crest is broad and lies closer to core hole LBCH (Figure 7). This latest episode of folding may have begun as early as lower Wilmington time, but certainly by Bent Spring time as evidenced by the formation of the Palos Verdes basin along the fold's south flank. Folding continued at least through Mesa time. This is evidenced by northeast dips in Mesa and Pacific sediment in core hole LB Webster, northeast tilting of the Long Beach plain from the coastline northeast toward Signal Hill, and gentle anticlinal warping of the Mesa surface in the Torrance plain. We see no clear evidence for folding of the Dominguez sequence, but a small amount of tilting cannot be ruled out.

A result of the folding pertinent to ground-water investigations is the occurrence of local stripping of the uppermost portions of the younger sequences along the crest of the fold. Coastal deposits that tend to occur as fining-upward packages dominate the Mesa, Pacific, and Harbor sequences. As a result of uplift along the fold crest (in addition to the faulting discussed below), these uppermost fine-grained deposits would be preferentially removed, resulting in fewer and more laterally discontinuous aquitards along the fold crest. That this phenomenon has occurred is clearly demonstrated by comparing the nature of the stratigraphic sequences in $\mathrm{LBCH}$, which occurs at the fold crest, and LB Webster, which is on the fold's northeast flank. LBCH has very few fine-grained intervals in the Harbor sequence, and the Mesa and Pacific sequences have been completely stripped away (Figure 12). LB Webster, in contrast, has all three sequences intact, including the fine-grained capping intervals (Figure 4). 


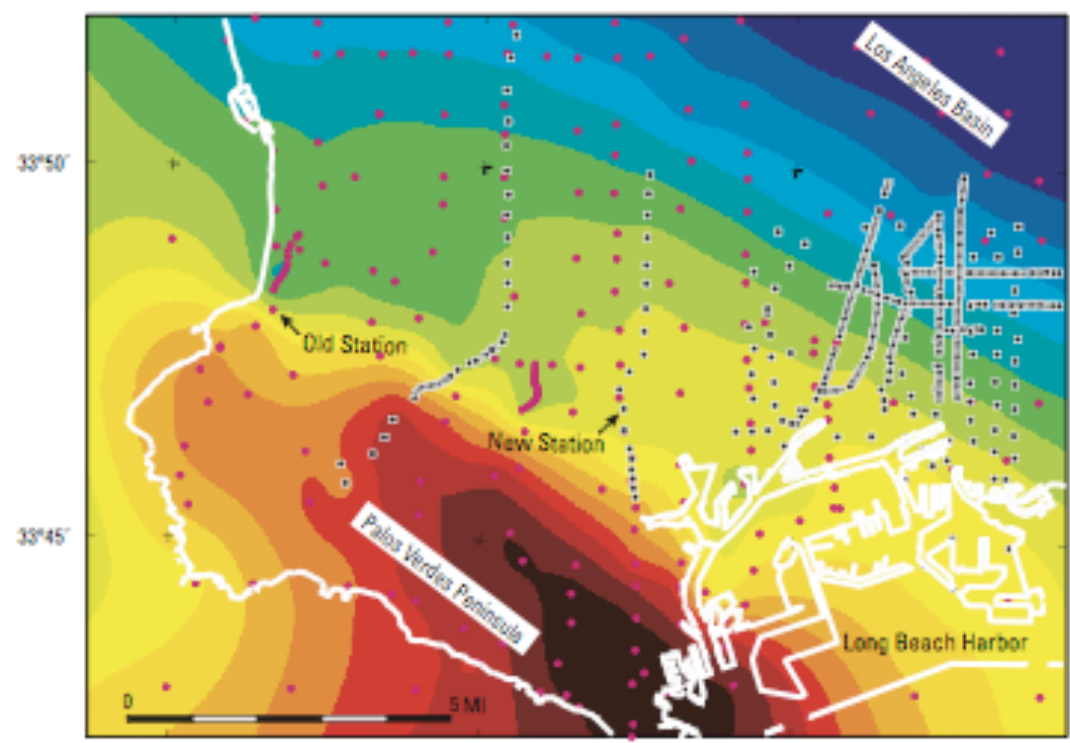

(a)
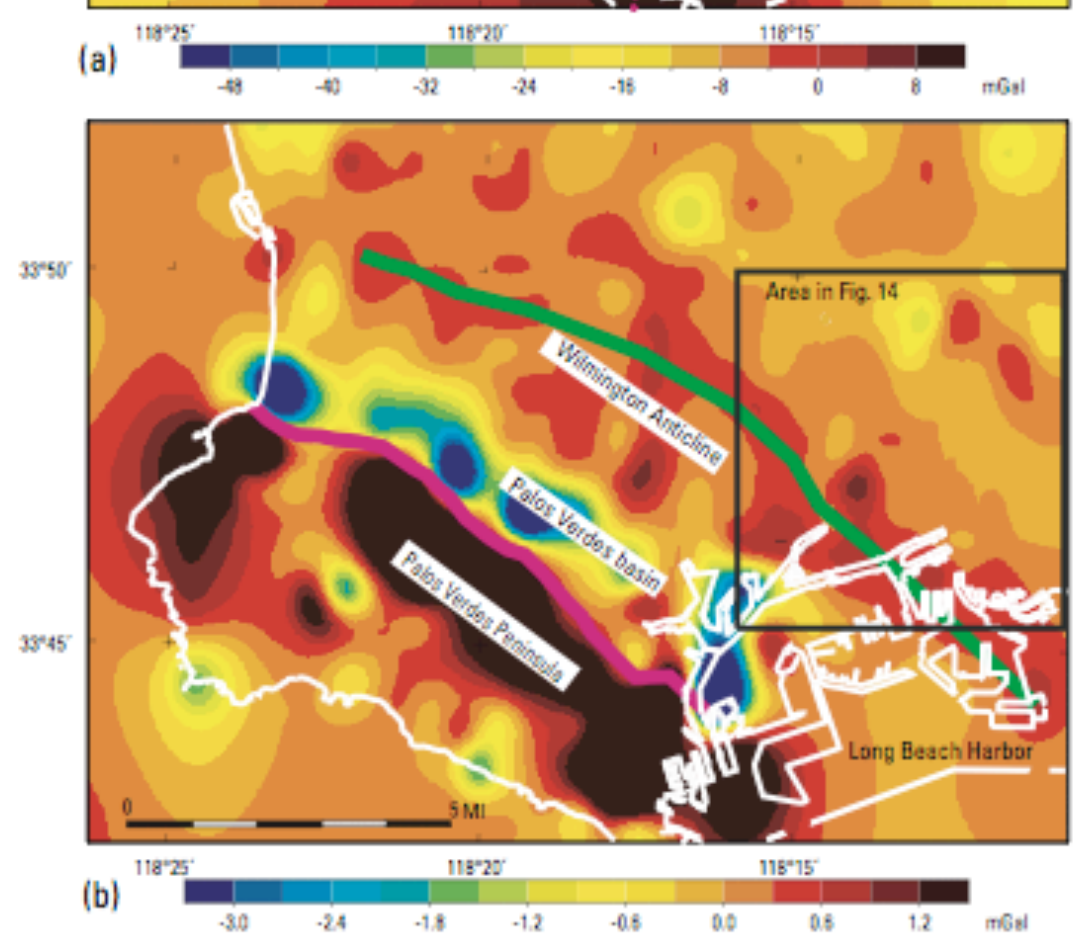

Figure 13. (a) Isostatic gravity anomaly, which characterizes lateral changes in density primarily in the upper crust, was compiled from existing gravity stations (magenta), supplemented by over 600 new measurements (black squares). Pronounced highs (warm colors) occur over the dense, shallow Catalina schist in the Palos Verdes Peninsula area that contrast with the deep gravity lows (cool colors) associated with thickening of lower-density sedimentary Cenozoic rocks northeastward into the Los Angeles Basin. (b) Residual isostatic gravity anomaly produced using a match filter in order to enhance shallow density sources. The approximate crest of the Wilmington anticline is shown as the green line. The anticline is flanked to the southwest by the narrow (3-km wide) Palos Verdes basin. The Palos Verdes fault (magenta line) marks the sharp density contrast between the dense Catalina schist and low-density sediment (primarily belonging to the Bent Spring sequence) in the Palos Verdes basin. Black box highlights Long Beach area shown in Figure 14. 
Complicating the fold geometry is the presence of a system of faults near the fold crest. Faulting appears to be closely associated with the younger phase of fold growth but may pre-date fold initiation. A major W-NW trending structure, or series of en echelon structures, is observed to cross the Dominguez barrier alignment between wells $360 Z$ and 370 U V (Figure 8). We informally call this structure the Pacific Coast Highway $(\mathrm{PCH})$ fault given that faulting intersects the barrier near Pacific Coast Highway. Displacement sense on the PCH fault is generally down to the north, with maximum vertical separation of perhaps $250 \mathrm{~m}$ at the eastern end of the study area. There are poor constraints on the occurrence of the PCH fault east of the Los Angeles River in the Long Beach plain, but there is some suggestion that the fault continues to the E-SE across the Long Beach plain where it may merge with the NewportInglewood fault. This is implied by seismic data in San Pedro Bay that clearly show that the sequences continue to climb in altitude northeastward toward the coastline, whereas well data onshore suggest that correlative sequences occur at significantly lower altitudes. For example, the top of the Upper Wilmington sequence reaches an altitude of - 35 m near the coastline in the eastern portion of San Pedro Bay, yet appears to occur at an altitude of $\sim-150 \mathrm{~m}$ in a well located only about $1 \mathrm{~km}$ inland from the coast (Figures 1 and 10). The well control that does exist east of the Los Angeles river, along with limited gravity data, also indicates that there may be a $\sim 2 \mathrm{~km}$-wide right-step or bend in thefault, suggesting that the PCH fault may in fact consist of a series of en echelon steps. Our present model illustrates this step as a kink in the fault (as shown in Figure 1). This was done to simplify the model; however, one or more en echelon steps may well be more representative of the fault's true geometry. We have little data to constrain the fault to the west of its western terminus shown in Figure 1, although there is some suggestion in the gravity data as well as from oil field data that the fault may step to the north and continue westward into Torrance. Near the Dominguez barrier, the PCH fault cuts through at least the base of the Harbor sequence, and progressive vertical offset of sequences is noted from the top of the lower Wilmington through the base of the Harbor indicative of continued faulting during that time interval. Because the Mesa and Pacific sequences have been removed near the fold crest, we have no record preserved to evaluate whether the $\mathrm{PCH}$ fault continued to be active during Pacific and Mesa time. We do not observe any obvious geomorphic evidence for faulting of the top of the Mesa sequence at the ground surface, nor is there clear evidence for displacement of the base of the Dominguez sequence. As such, within our model we terminate the PCH fault at $-50 \mathrm{~m}$ altitude beneath the Dominguez sequence, and $-17 \mathrm{~m}$ altitude beneath the Long Beach Plain where there is some suggestion that the fault may reach to shallower depths. While we do not model the PCH fault to offset Holoceneage (Dominguez) deposits, we cannot rule out the possibility of small offsets (on the order of a meter or less) occurring on the PCH fault since deposition of the Mesa sequence. Nearly 600 local earthquakes in the southern California seismicity catalog, ranging in magnitude from M0.5 to M3.8, have been recorded proximal to the $\mathrm{PCH}$ fault since 1950. Unfortunately, the locations for most of these events are too poorly constrained to be able to determine whether any of them could be directly attributable to this fault.

In addition to the principal $\mathrm{W}$-NW-trending $\mathrm{PCH}$ fault, well data suggest the existence of at least two N-NW-trending ancillary faults that likely merge with the $\mathrm{PCH}$ fault. These faults, informally named the Richfield and Scott Park faults, apparently ceased activity between Upper Wilmington and Harbor time. We therefore model the Richfield and Scott Park faults to terminate at altitudes of $-150 \mathrm{~m}$ and $-100 \mathrm{~m}$, respectively. Of the two faults, the Richfield fault is the best constrained from well data, and exhibits about $45 \mathrm{~m}$ of vertical separation, down to the northeast. The location and trend of this fault is similar to the Richfield fault reported in Zielbauer and others (1962), and it affects the same units, which is the reason for adopting the same name. However, the displacement sense that we observe in the stratigraphy, and that is also supported by gravity data, is the opposite of that inferred by Zielbauer 
and others. This discrepancy may be a result of the fact that Zielbauer and others' (1962) correlations are based on different criteria (similar lithologies) that could have resulted in an erroneous view of the overall geologic structure. The Scott Park fault is less well constrained from well data and we rely heavily on gravity data to assist in constraining its location and strike, which approximately parallels that of the Richfield fault. Well data suggest a maximum vertical separation within the uppermost $900 \mathrm{~m}$ to be $\sim 60$ m down to the southwest

While recognition of the $\mathrm{PCH}$ fault and its ancillary faults is new, observations that would support faulting along its trend are not new. Zielbauer and others (1962) recognized that the Silverado aquifer became much finer grained south of Pacific Coast Highway. They attributed this to a facies change, which caused them to deepen and thin the Silverado to the south. With the addition of additional wells and more well data, it became obvious that lithologic change in what was considered to be the Silverado aquifer occurred over too short a distance to be easily explained in this fashion. Ehman and others (2001) therefore proposed that the southern margin of the Silverado was formed from channel incisions, with the Silverado aquifer itself inset into older sediment. This conclusion was supported by core samples from the LB Webster well indicating that the Silverado aquifer contained river or deltaic distributary channels, with likely E-W flow directions, and core samples from Pier $\mathrm{C}$ that indicated relatively old sediment near the surface south of Pacific Coast Highway. Using this model, and the fact that the Silverado aquifer is considerably denser than the surrounding sediment, we began to use high-resolution gravity data to test whether the southernmost edge of the Silverado "channel" could be identified and mapped (Figure 14). The resulting gravity model, however, required that the underlying Tertiary bedrock also be displaced in a similar fashion and by a similar amount (Figure 15) an observation that cannot be readily explained by channel erosion. Further examination of the gravity data reveals a number of steep gravity gradients, suggestive of basement faulting with down-to-thenortheast and down-to-the-southwest displacements. These gravity gradients are nearly coincident with where we would locate the PCH, Richfield and Scott Park faults based only on well constraints (Figure 16).

Published oil industry data supports the existence of a fault similar in character and location to our proposed PCH fault. Wright (1991, Figures 9 and 10, p.52-53) shows a possible (queried) W-NW trending, north-dipping fault that displaces the base Repetto and base Mohnian-age rocks at depths of approximately 4000 and 8000 feet, respectively (1219 to 2438 meters). This possible fault is nearly coincident with the PCH fault we define in the shallow subsurface. Normal displacement is indicated (down to the northeast) of up to 1000 feet (300 meters), again nearly identical to our current estimates for the overall separation of the oldest Pleistocene sequences. Wright (1991, Figure 8, p. 51) shows this possible structure to displace base Pico, but does not project it higher in the section. Farther to the west along trend in Torrance, Davis and others (1989, Plate 1), show in cross-section a similar fault with comparable sense and amount of displacement. They, too, do not project the fault into the late Pleistocene. We suggest that the queried fault identified by Wright (1991) and Davis and others (1989) is real and is in fact the PCH fault. Our data, however, indicates that the fault is a Quaternary, not Tertiary, structure, that began to move perhaps as early as lower Wilmington time, with significant displacement occurring during upper Wilmington time. Movement on the fault also served to confine the coarse deltaic facies of the upper Wilmington sequence (classic Silverado aquifer) to its the north (down-dropped) side.

Although our data only reveals the vertical component of faulting, the strike of the $\mathrm{PCH}$ fault and associated anticlinal folding suggest that the fault system as a whole is most likely reverse-rightoblique, similar to the Palos Verdes fault onshore (Ward and Valensise, 1994; McNeilan and others, 1996). Well data suggest that the fault has a steep dip $\left(>70^{\circ}\right)$, which is suggestive of a significant strike- 
slip component. The older, N-NW-trending Richfield and Scott Park faults may represent NW-trending en echelon tears that formed within a broad shear zone prior to shear concentrating on the principal strands of the PCH fault. Current data suggest that the PCH fault exhibits one or more right steps, which would result in localized tension that could account for the observed vertical displacements as well as localized normal displacements.

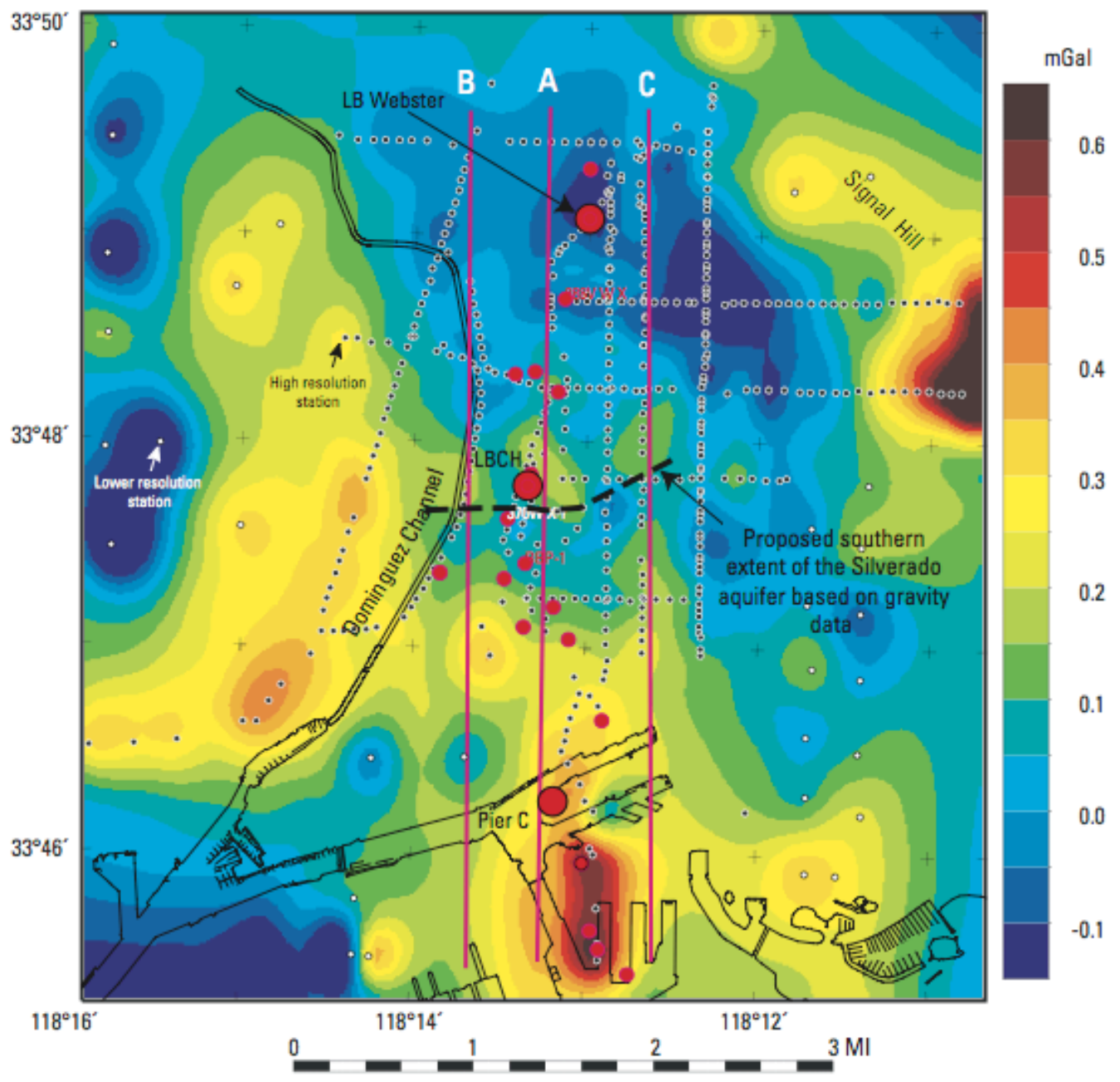

Figure 14. Residual isostatic gravity data. The black circles mark areas where high-resolution gravity data (accuracy better than $0.05 \mathrm{mGal}$ ) were collected; white circles show less accurate ( $0.5 \mathrm{mGal})$ data. The regional gravity highs along Signal Hill and west of the Dominguez Channel are caused by the shallowing of denser sedimentary units. Red circles mark the locations of wells used to constrain the density models. Density models were developed along 3 profiles $A, B$, and $C$; the results along profile $A$ are shown in Figure 15.

\section{Discussion}

The sequence stratigraphic model introduced here represents a significant advance in our understanding of the depositional character and structural setting of the geologic sequences that contain ground-water in the Dominguez gap region. An important new discovery from this approach is the recognition of ongoing tectonic deformation throughout nearly all of Quaternary time that has impacted 
the geometry and character of the sequences. This deformation is represented by anticlinal folding and uplift along a trend similar to, but displaced several kilometers north of, the Wilmington anticline. Near the fold crest, a W-NW trending fault system, the $\mathrm{PCH}$ fault, has been identified that displaces most of the sequences down to the north by as much as 250 meters.

One implication from the new evaluations is that some aquifer units as presently defined appear to occur in multiple sequences. Thus, aquifers presumed to be hydraulically linked in fact fall into different genetically related sediment packages. We suggest that ground-water flow between coarse-grained packages of sediment that are contained within different sequences likely occurs where these coarsegrained deposits are juxtaposed across the PCH fault, across the incised channel that contains the Dominguez sequence, or across sequence boundaries where capping fine-grained aquitards may have been removed by erosion, such as observed near the crest of the young anticline. All of the above scenarios of possible pathways for fluid migration between sequences appear to be present in the Dominguez gap region. Incision of the Dominguez sequence into underlying Pacific, Mesa, and Harbor sequences provides the opportunity for saline waters of the Gaspur aquifer to migrate laterally and downward into these systems. This will occur most extensively beneath and adjacent to the Dominguez sequence along the crest of the new fold, near Pacific Coast Highway. The likelihood for lateral migration of saline waters into older aquifers was recognized by Zielbauer and others (1962) and it is this mechanism of invasion that the current barrier is designed to militate against. Our current model suggests, however, that locally the Dominguez sequence also has incised into the Bent Spring and upper Wilmington sequences south of the $\mathrm{PCH}$ fault. The upper Wilmington sequence is relatively finegrained south of the fault, but portions of the Bent Spring are transmissive and could provide a conduit for saline waters to migrate inland below the Gaspur aquifer channel deposits where they could invade lower portions of the Harbor sequence (e.g. Lynwood aquifer) north of the PCH fault.

We have not tested for certain whether the PCH fault acts as a ground-water barrier or a conduit for fluid flow between sequences, although the fact that this structure was not recognized in previous ground-water studies suggests that the fault likely does not serve as a significant barrier to flow. If this is the case, fluid flow across the $\mathrm{PCH}$ fault is likely where coarse-grained deposits are juxtaposed across the fault. From our model, it appears that sandy facies of the Pliocene B, Pliocene A, and lower Wilmington sequences south of the $\mathrm{PCH}$ fault are juxtaposed against coarse-grained facies of the upper Wilmington sequence (Silverado aquifer) to the north. Data from Pier $\mathrm{C}$ indicates that waters from Pliocene B and A are relatively low in chloride, but have higher levels of sodium bicarbonate and dissolved solids than typical Silverado waters (Land and others, 2004). Extensive landward migration of Pliocene B and A waters into the Silverado across the PCH fault could serve to degrade the quality of the Silverado water along this pathway

Late Pleistocene folding that involves the Harbor, Pacific, and Mesa sequences has resulted in significant erosion and thinning of these deposits along the crest of the young fold. The paralic deposits that comprise these sequences typically fine upward, such that subsequent erosion preferentially removes capping fine-grained beds that might otherwise serve to protect the underlying aquifers. A greater potential therefore exists for vertical migration of seawater into the producing aquifers of the Bent Spring and upper Wilmington sequences (Silverado aquifer) where the capping fine-grained beds are missing. One observation that indicates that vertical migration of saline waters may be occurring progressively inland is that in LB Webster, located landward of the new barrier extension, there is a higher concentration of chlorides in the Harbor sequence at a depth of 277 feet ( 84 meters; Land and others, 2004) than there is in the overlying Dominguez sequence (Gaspur aquifer). This is not the case 

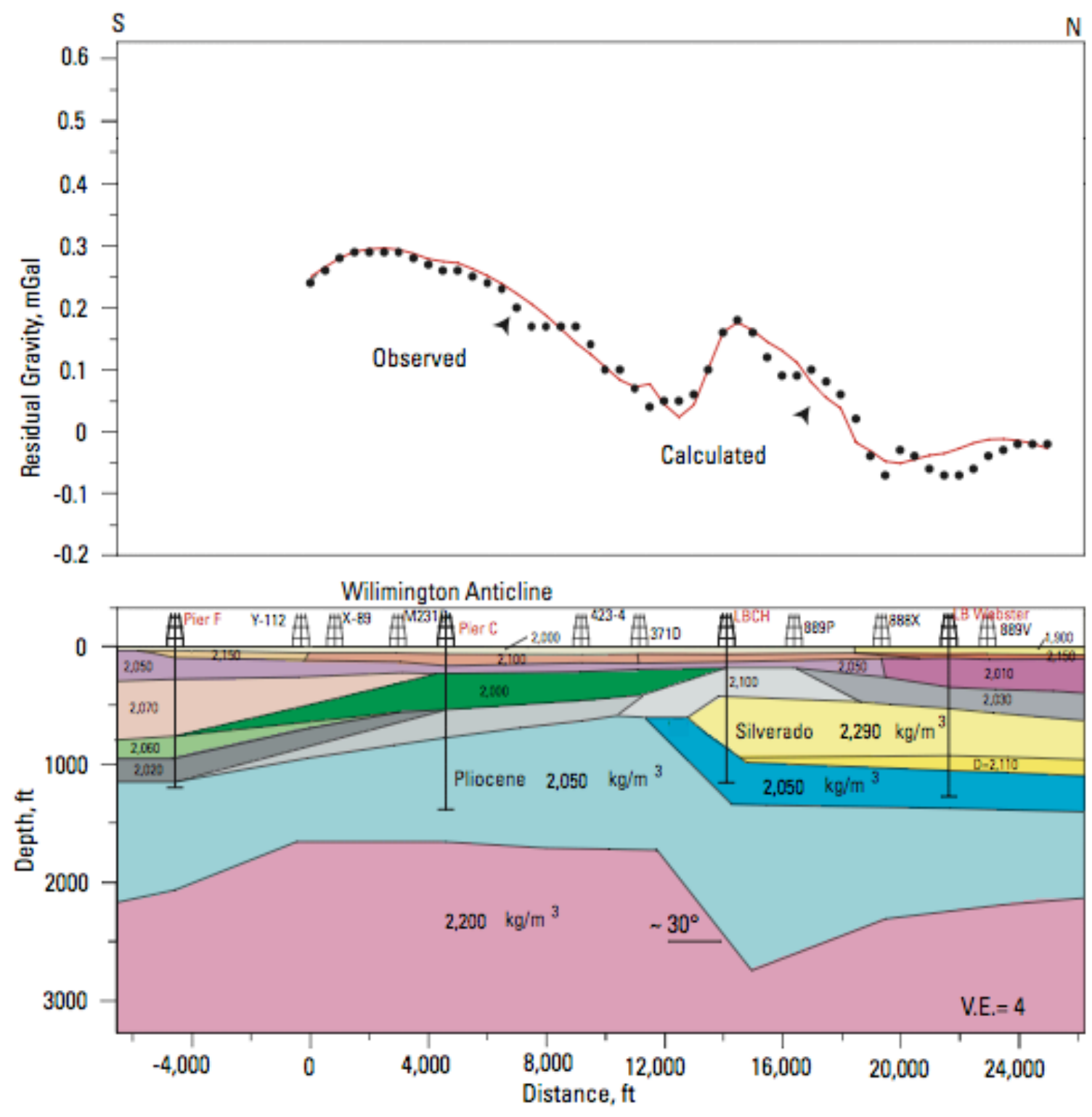

Figure 15. Inversion of gravity data along Profile A (figure 13) showing computed and actual gravity fields (upper diagrams) and model (lower diagrams). Using the density information from wells drilled for this study (LB Webster, LBCH, Pier C and Pier F) and depths to layers based on intervening wells, the upper parts of the model are mostly fixed. Between wells the dip and extent of layers could be varied to obtain a better match between the observed and calculated gravity data. In the vicinity of $\mathrm{LBCH}$, because the coarse-grained (Silverado aquifer) facies of the Upper Wilmington sequence has a density considerably greater than those of adjacent layers, the gravity near the LBCH well helps to delineate the southern termination of the Silverado, which is less than $2000 \mathrm{ft}$ south of $\mathrm{LBCH}$. Using the modeling results of all three profiles, the estimated southern extent of the Silverado roughly has an east-west strike (dashed black line, figures 14 and 16). A down-to-the-north step in the top of the Tertiary Undifferentiated unit near LBCH (pink layer at the bottom of the profile) is required in the model. Such a step coincident with the southern termination of the Silverado facies of the Upper Wilmington sequence is indicative of a fault (Pacific Coast Highway fault). The existence of this fault is also suggested by the high gravity gradient in the residual data and from well correlations. 


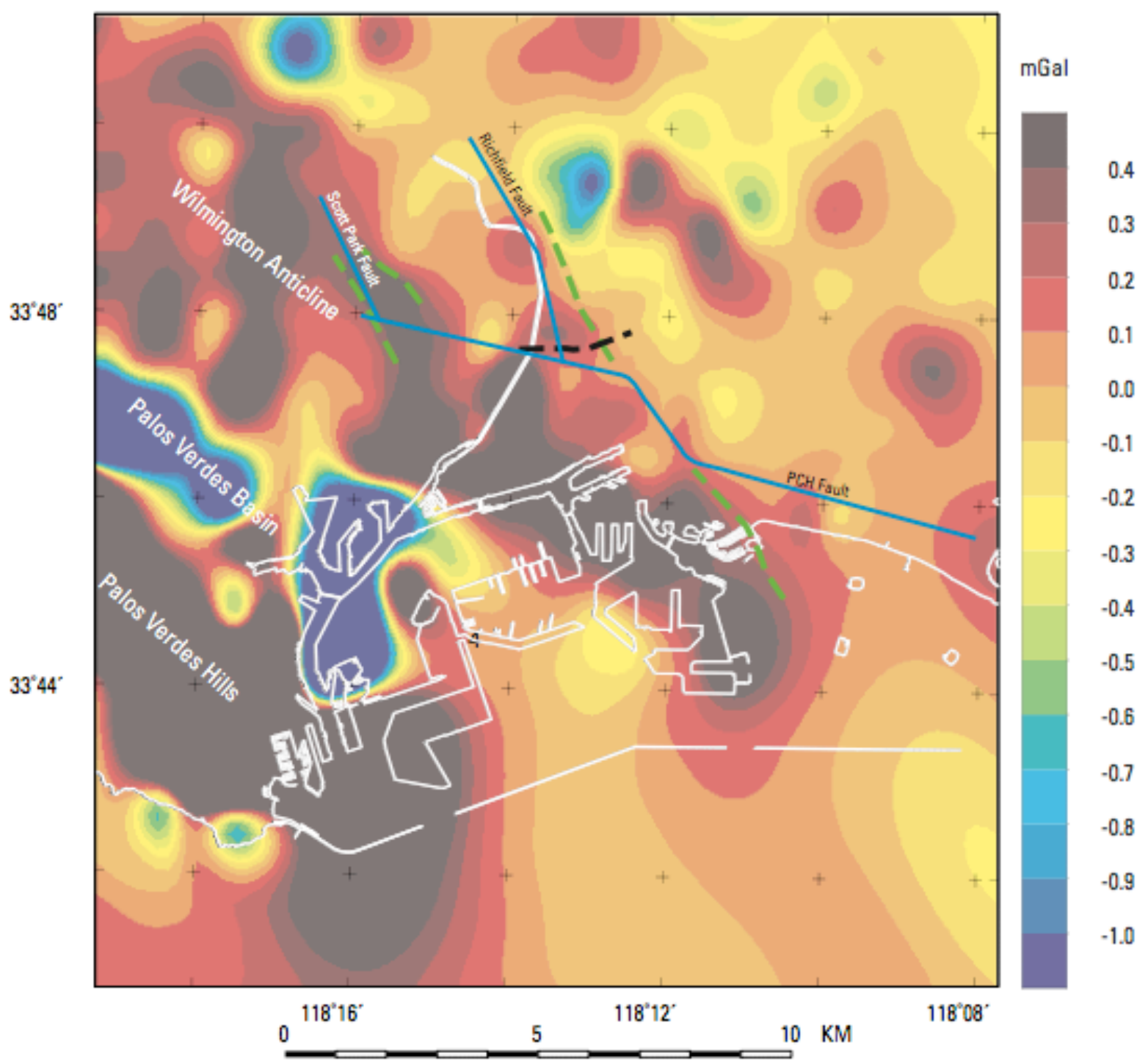

Figure 16. Residual gravity map of the Dominguez gap region showing the relationship between gravity and possible fault strands. Warm colors are where residual gravity is high, reflecting regions of denser rock at shallow depths in the subsurface. Cool colors are gravity lows, where lower density materials are thickest. The Wilmington anticline and Palos Verdes Hills are clearly expressed as gravity highs whereas the sediment-filled Palos Verdes basin is in blue. The "bullseye" nature of some of the contours reflects the spotty data coverage in parts of the area. Light green dashed lines show some areas of high gravity gradient on the north side of the anticline. These lineaments coincide fairly closely with the locations of the Richfield, Scott Park, and Pacific Coast Highway (PCH) faults as constrained by well data. The black dashed line marks the southernmost extent of the thick, sandy deltaic complex of the Upper Wilmington sequence (classic Lower Silverado aquifer) as derived from very high-resolution gravity measurements (figures 14 and 15). This boundary also corresponds fairly closely to the PCH fault and suggests that the fault (which was active during Upper Wilmington deposition) served to control the location of the distributary channels within the delta complex. 
$2.5 \mathrm{~km}$ to the south (closer to the shoreline), at the $\mathrm{LBCH}$ core hole, where the highest chloride concentrations occur within the Gaspur aquifer and uppermost Harbor sequence at depths shallower than $200 \mathrm{ft}(61 \mathrm{~m})$.

Data from the LBCH core hole, located north of the PCH fault and near the crest of the fold, clearly shows that invasion of aquifers of the Bent Spring and upper Wilmington sequences (Silverado aquifer) is already occurring seaward of and beneath the barrier. Within LBCH, few fine-grained intervals occur above the upper Wilmington sequence. Waters containing relatively high concentrations of chloride in the Bent Spring sequence (upper Silverado aquifer) and uppermost upper Wilmington sequence (lower Silverado aquifer) are observed to a depth of 440 feet (134 meters) below land surface. If further landward and vertical migration were to continue within the upper Wilmington sequence, these invaded waters would flow beneath the existing barrier wells. At present, it is not clear whether or to what degree current barrier operations may serve to stem further landward movement within the upper Wilmington sequence.

The sequence-based approach to delineating the stratigraphy of the Dominguez Gap region, and construction of the 3-D model, provides a new view as to how and where coarse-grained, water-bearing facies of the various depositional sequences may interconnect. This new interpretation of the stratigraphy may have important implications for seawater intrusion management. To test the significance, and to better evaluate how effective current barrier operations may be at preventing landward migration of seawater, it is suggested that water level and water-quality data from the barrier wells be overlain onto the new framework, and that the new stratigraphic layering be incorporated into a ground-water transport model. In addition, continued monitoring of wells at LBCH and other wells that tap the upper Wilmington aquifers, including water sampling and EM logging, should be pursued to determine whether further landward flow or vertical migration of saline waters is occurring.

\section{References Cited}

Bassinot, F. C., Labeyrie, L. D., Vincent, E., Quidelleur, X., Shackleton, N. J., and Lancelot, Y., 1994, The astronomical theory of climate and the age of the Brunhes-Matuyama magnetic reversal: Earth and Planetary Science Letters, v. 126, p. 91-108.

Bull, W. B., 1991, Climatic Geomorphology, Oxford University Press, 326 p.

California Dept. of Water Resources, 1961, Planned utilization of the ground water basins of the coastal plain of Los Angeles County, Appendix A, Ground Water Geology: California Department of Water Resources Bulletin 104, 191 p.

Cande, S. C., and Kent, D. V., 1995, Revised calibration of the geomagnetic polarity timescale for the Late Cretaceous and Cenozoic: Journal of Geophysical Research, v. 100, p. 6093-6095.

Champion, D. E., Lanphere, M. A., and Kuntz, M. A., 1988, Evidence for a new geomagnetic reversal from lava flows in Idaho: Discussion of short polarity reversals in the Brunhes and late Matuyama polarity chrons: Journal of Geophysical Research, v. 93, p. 11667-11680.

Clarke, D. D., and Phillips, C. C., 2003, Three-dimensional geologic modeling and horizontal drilling bring more oil out of the Wilmington oil field of southern California, in T. R. Carr, E. P. Mason, and C. T. Feazel, eds., Horizontal wells: Focus on the reservoir: AAPG Methods in Exploration No. 14, p. 27-47.

Dartnell, P., Gardner, J.V., Mayer, L.A., Clark, J.E.H., 2004, Los Angeles and San Diego margin highresolution multibeam bathymetry and backscatter data: U.S. Geological Survey Open-File Report 2004-1221, accessed August 1, 2005 (http://pubs.usgs.gov/of/2004/1221/) 
Davis, T. L., Namson, J., and Yerkes, R. F., 1989, A cross section of the Los Angeles area: Seismically active fold and thrust belt, the 1987 Whittier Narrows earthquake, and earthquake hazard: Journal of Geophysical Research, v. 94, p. 9644-9664.

Ehman, K. D., Ponti, D. J., Clifton, H. E., Edwards, B. D., Fleck, R. J., Hillhouse, J. W., Mahan, S. A., McDougall, K., Powell, C. L., II, Tinsley, J.C, III, 2001, Quaternary stratigraphy and hydrostratigraphy of the Long Beach area, southwest Los Angeles basin, CA: Geological Society of America Abstracts with Program, v. 33, no. 3, p. A77

Guyodo, Y. and Valet, J-P., 1999, Global changes in intensity of the Earth's magnetic field during the past 800 kyr: Nature, v. 399, p. 249-252.

Hoffman, K. A., and Singer, B. S., 2004, Regional recurrent paleomagnetic transitional fields and mantle processes, in Timescales of the Paleomagnetic Field, American Geophysical Union Monograph Series, 145, p. 233- 243.

Imbrie, J., Hays, J.D., Martinson, D.G., McIntyre, A., Mix, A.C., Morley, J.J., Pisias, N.G., Prell, W.L., and Shackleton, N.J., 1984, The orbital theory of Pleistocene climate: support from a revised chronology of the marine $\delta^{18} \mathrm{O}$ record in Berger, A., Imbrie, J., Hays, J., Kukla, G, and Saltzman, B, eds, Milankovich and Climate, part 1: Plenum Reidel, Dordrecht, pp. 269-305.

Kucera, M. and Kennett, J.P., 2000, Biochronology and evolutionary implications of late Neogene California margin planktonic foraminiferal events: Marine Micropaleontology, v. 40, p. 67-81.

LACDPW Geology Investigations Unit, 2003, Drilling summary report, Dominguez gap barrier project, Unit 7B, Phase 4A, Part 1: Los Angeles County Department of Public Works unpublished report, 24 p.

Land, M., Everett, R.R., and Crawford, S.M., 2002, Geologic, hydrologic, and water-quality data from multiple-well monitoring sites in the Central and West Coast Basins, Los Angeles County, California: U.S. Geological Survey Open-File Report 01-277, 178 p

Land, M., Reichard, E.G., Crawford, S.M., Everett, R.R., Newhouse, M.W., and Williams, C.F., 2004, Ground-Water Quality of Coastal Aquifer Systems in the West Coast Basin, Los Angeles County, California, 1999-2002: U.S. Geological Survey Scientific Investigations Report 2004-5067, 80 p.

Lanphere, M. A., Champion, D. E., Christiansen, R. L., Izett, G. A., and Obradovich, J. D., 2002, Revised ages for tuffs of the Yellowstone Plateau volcanic field: Assignment of the Huckleberry Ridge Tuff to a new geomagnetic polarity event: Geological Society of America Bulletin, v. 114, p. 559-568.

Mayuga, M.N., 1970, Geology and development of California's giant - Wilmington oil field, in Geology of giant petroleium fields - symposium: American Association of Petroleum Geologists Memoir 14, p. 158-184.

McNeilan, T. W., Rockwell, T. K, and Resnick, G. S., 1996, Style and rate of Holocene slip, Palos Verdes fault, southern California: Journal of Geophysical Research. v. 101, no. B4, p. 8317-8334.

Norton, T.A. and Otott Jr., G.E., 1996, The stratigraphy of the Wilmington oil field, in Clarke, D.D., Otott Jr., G.E. and Phillips, C.C. eds, Old Oil Fields and New Life: A Visit to the Giants of the Los Angeles Basin: American Association of Petroleum Geologists Guide Book 74, pp.23-36.

Poland, J.F., Piper, A.N., and others, 1956, Ground water geology of the coastal zone, Long Beach, California: U.S. Geological Survey Water Supply Paper 1109, 162 p.

Ponti, D.J., 1989, Aminostratigraphy and chronostratigraphy of Pleistocene marine sediments, southwestern Los Angeles basin: Ph.D. Dissertation, University of Colorado, Boulder, 409p.

Tucholka, P., Fontugne, M., Guichard, F., and Paterne, M., 1987, The Blake magnetic polarity episode in cores from the Mediterranean Sea: Earth and Planetary Science Letters, v. 86, p. 320-326. 
Reichard, E.G., and others, 2003, Geohydrology, geochemistry, and ground-water simulationoptimization of the Central and West Coast basins, Los Angeles County, California: U.S. Geological Survey Water-Resources Investigations Report 03-4065, 184 p.

Ward, S. N, and Valensise, G, 1994, The Palos Verdes terraces, California; bathtub rings from a buried reverse fault: Journal of Geophysical Research, B, Solid Earth and Planets, v.99, no.3, p.4485-4494.

Weldon, R.J., 1986, Late Cenozoic geology of Cajon Pass: implications for tectonics and sedimentation along the San Andreas fault: California Institute of Technology, Ph.D. thesis, 400 p.

Weldon, R.J., 1989, Origin of fill terraces in the central Transverse Ranges, California: Transactions, American Geophysical Union, v. 70, no. 43, p. 1125.

Woodring, W.P., Bramlette, M.N., and Kew, W.S.W., 1946, Geology and paleontology of Palos Verdes Hills, California: U.S. Geological Survey Professional Paper 207, 145 p.

Wright, T.L., 1991, Structural geology and tectonic evolution of the Los Angeles basin, California, in Biddle, K.T., Active margin basins: American Association of Petroleum Geologists Memoir 52, p. 35 134.

Zielbauer, E.J., Kues, H.A., Burnham, W.L., Keene, A.G., 1962, Coastal basins barrier and replenishment investigation, Dominguez gap barrier project geologic investigation: Los Angeles County Flood Control District unpublished report, 26 p. 